\title{
Preliminary Report on the Third Season of the Konya-Ereğli Survey (Keyar) 2015
}

\section{Çiğdem Maner}

\section{Q OpenEdition \\ 1 Journals}

\section{Electronic version}

URL: http://journals.openedition.org/anatoliaantiqua/384

DOI: 10.4000/anatoliaantiqua.384

\section{Publisher}

IFEA

\section{Printed version}

Date of publication: 1 May 2016

Number of pages: 225-252

ISBN: 9782362450648

ISSN: 1018-1946

\section{Electronic reference}

Çiğdem Maner, "Preliminary Report on the Third Season of the Konya-Ereğli Survey (Keyar) 2015", Anatolia Antiqua [Online], XXIV | 2016, Online since 11 December 2018, connection on 16 February 2021. URL: http://journals.openedition.org/anatoliaantiqua/384 ; DOI: https://doi.org/10.4000/ anatoliaantiqua.384 


\section{ANATOLIA ANTIQUA ESKI ANADOLU}

\section{XXIV}

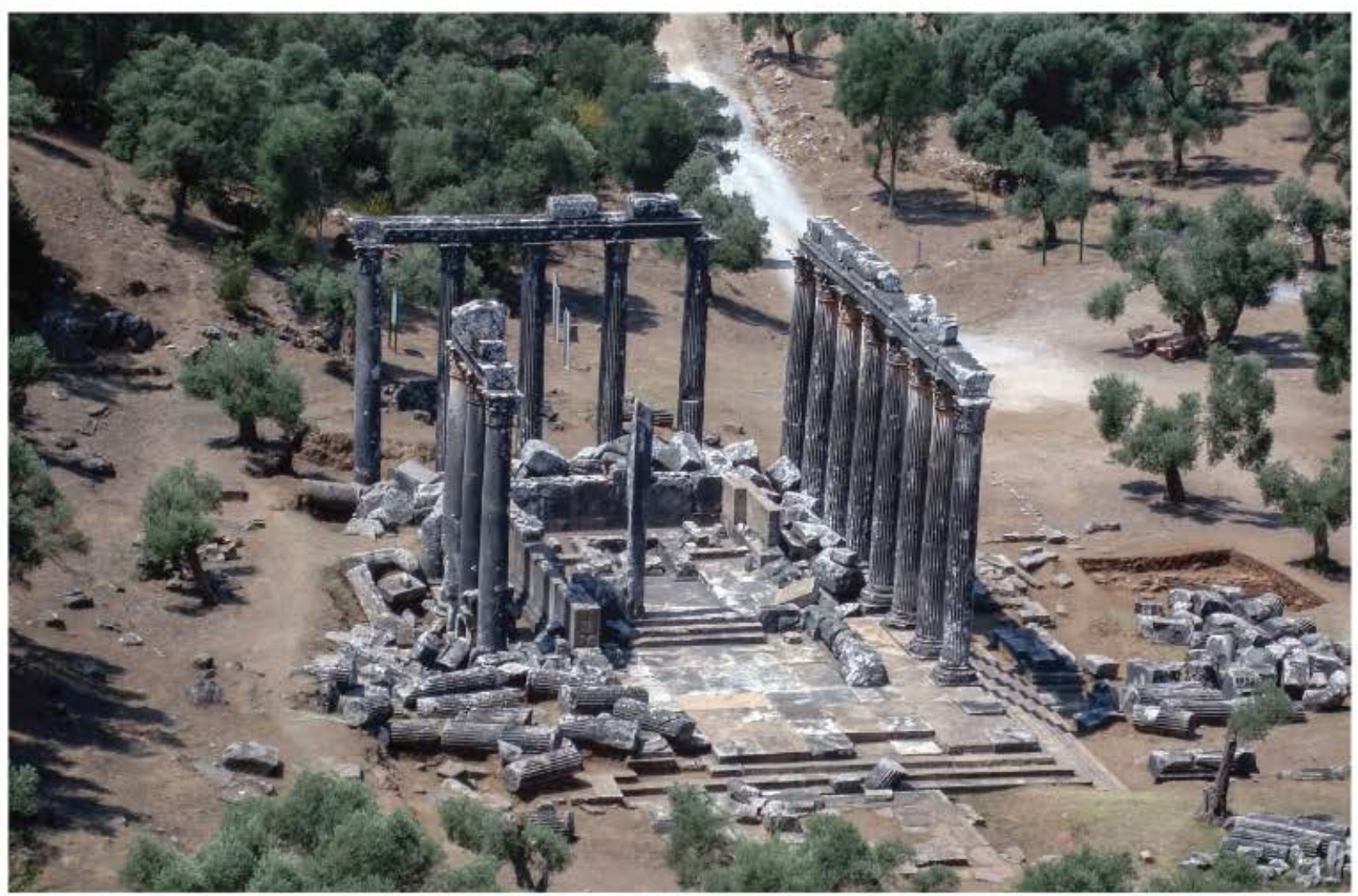

INSTITUT FRANÇAIS D'ETUDES ANATOLIENNES GEORGES-DUMEZIL

CNRS USR 3131

DE BOCCARD 


\section{TABLE DES MATIERES}

Ergul KODAS,

Le surmodelage du crâne au Néolithique au Proche-Orient : techniques de surmodelage et

expérimentations

Isabella CANEVA et Eric JEAN,

Mersin-Yumuktepe : une mise au point sur les derniers travaux

Turan EFE et Bérengère PERELLO,

Second Millenium site distribution and pottery of Inland Northwestern Anatolia

Antoine PEREZ,

Amida 6 : Antiochos IV, le "Hanigalbat" et la Sophène

Ergün LAFLI et Hadrien BRU,

Inscriptions et monuments funéraires gréco-romains d'Anatolie occidentale

Oğuz TEKİN et Aliye EROL-ÖZDİZBAY,

Coins from Allianoi excavations: Campaign of 2001

Nuran ŞAHIN,

Etude iconographique des monnaies autonomes frappées par Colophon-sur-Mer :

nouveaux acquis

Vera SAUER,

Konventionelle Individualität. Zur Münzprägung nordanatolischer Städte in der römischen

Kaiserzeit

Oğuz TEKIN,

Balance weights in the collection of the Anatolian Civilizations Museum in Ankara

\section{CHRONIQUES DES TRAVAUX ARCHEOLOGIQUES EN TURQUIE 2015}

Çiğdem MANER,

Preliminary report on the third season of the Konya-Ereğli Survey (KEYAR) 2015

Dominique BEYER, Isabelle CHALIER et Françoise KIRNER,

Rapport préliminaire sur les travaux de la mission archéologique de Zeyve Höyük-Porsuk 2015 ...

Sami PATACI et Ergün LAFLI,

Field surveys in Ardahan in 2015

Jean-Charles MORETTI avec la collaboration de Nicolas BRESCH, Isabel BONORA,

Jean-Jacques MALMARY et Olivier RISS,

Claros, le temple d'Apollon : travaux réalisés en 2015

Serdar Hakan ÖZTANER,

La basilique civile de Nysa du Méandre

Abuzer KIZIL, Koray KONUK, Patrice BRUN, Laurent CAPDETREY, Raymond DESCAT,

Pierre FROHLICH, Didier LAROCHE, Enora LE QUERE, Francis PROST, Baptiste VERGNAUD,

Eurômos : rapport préliminaire sur les travaux réalisés en 2015

O. HENRY et E. ANDERSON, Chr. BOST, Ö. ÇAKMAKLI, F. CEDERLING, A. COMMITO,

M. CORMIER-HUGUET, A. COUTELAS, A. DOLEA, D. ERGENÇ, A. FRECCERO,

A. FREJMAN, P. LEBOUTEILLER, F. LESGUER, D. LÖWENBORG, V. LUNGU,

Fr. MARCHAND-BEAULIEU, A. SITZ, P. DE STAEBLER, B. VERGNAUD, 


\section{Çiğgem MANER*}

\section{PRELIMINARY REPORT ON THE THIRD SEASON OF THE KONYA-EREĞLİ SURVEY (KEYAR) ${ }^{1} 2015$}

The Konya Ereğli Survey project (KEYAR) started in 2013 with the aim of surveying the Bronze and Iron Age settlements of the provinces of southeastern Konya, which are Ereğli, Halkapınar, Emirgazi and Karapınar ${ }^{2}$. The third campaign of the archaeological survey took place between 17.08-14.09.2015 with the generous permission of the Ministry and Culture and Tourism of the Republic of Turkey, Directorate of Antiquities and Museum of the Republic of Turkey. Ms. Gülay Şahin from the General Directorate in Ankara was the representative of the third campaign. I am thankful to the Governor of Ereğli Mr. Ömer Lütfi Yaran, the governor of Halkapınar Mr. Erdal Çetinbaş, the major of Ereğli Mr. Özkan Özgüven, the major of Halkapınar Mr. Fahri Vardar and Mr. Mahmut Altuncan, director of the Ereğli Museum for their support during our stay and work.

The survey team consisted of academics and students, Assist. Prof. Sercan Yandım Aydın (Hacettepe University Department of Art History), students from Koç University (Muhip Çarkı M.A., Bihter Esener, Yavuz Selim Güler, Pelin Peker), Ege Unversity (Aybüke Nacar ve Asiye Toprak), Meltem Kaya (a high school student from Ereğli) and Mrs. Sadiye Kaya, who is our driver since 2013.

In addition to the archaeological survey, a geophysical survey was begun in two important settlements that had been surveyed in 2013 and 2014, namely Ereğli Karahöyük ${ }^{3}$ and Zencirli Höyük ${ }^{4}$. The geophysical survey was conducted by Dr. Ercan Erkul from the University of Kiel and Research Assistant İsmail Kaplanvural and his students from Kocaeli University Department of Geophysical Engineering between 25-27.08.2015. Without the cooperation and help of the whole team, the campaign wouldn't have been successful and I am grateful for their work and support.

The archaeological survey was generously supported by Koç University's College of Social Sciences and Humanities, Türk Tarih Kurumu and the Geophysical survey was financed through Koç University Seed Fund (SF 00013). The project is also supported by AVIS, generously providing a four-wheel drive car since 2014, and Özkoçlar Otel, Derya Lokantası and Serbey Turizm. We are also much obliged to the inhabitants of our survey area, who always open their houses and invite us for an ayran, glass of cold water or breakfast and lunch.

The 2015 survey season took place from late summer to the beginning of fall. It was generally a very hot and dry season and, according to the villagers, the hottest summer in a long time. The soil was dessicated and covered with dry, tall grass and hay, which prevented us most of the time from finding pottery on the ground. Also the dry soil made it difficult to climb up to the forts on the Taurus Mountains, as the soil was loose and crumbling. These conditions led to the decision that the next survey seasons will take place in June, when the soil is not as dry and the plants in the fields are still low.

\section{SETTLEMENTS INVESTIGATED IN 2015}

The survey area, which covers four provinces of southeastern Konya, covers an area of $c a .6242$ square $\mathrm{km}$. In 2013 the region east of Ereğli was investigated $^{5}$ (Map 1). In 2014 the archaeological survey continued in the north, west, south and east of Ereğli, in the north of Halkapınar and west of

\footnotetext{
*) Çiğdem Maner, Koç University, Department of Archaeology and History of Art, cmaner@ku.edu.tr

1) KEYAR: Konya Ereğli Yüzey Araştırması, Konya Ereğli Survey Project.

2) Maner 2014; 2015a; 2015b; Maner forthcoming.

3) Maner 2014: 355-7.

4) Maner 2015a: 252-6

5) Maner 2014; 2015a; 2015b.
} 


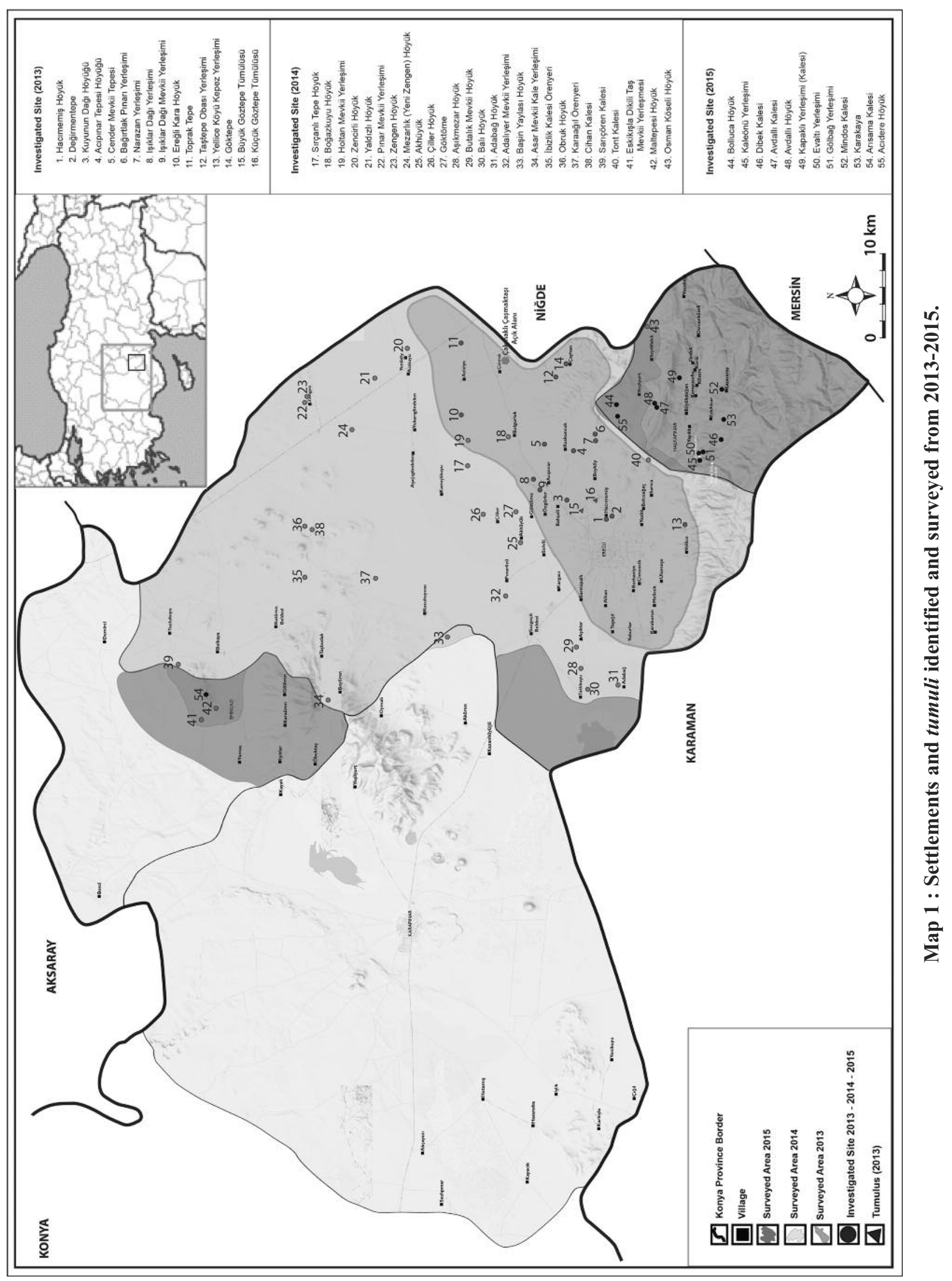


Table 1: Investigated and newly discovered sites of the 2015 campaign.

\begin{tabular}{|c|l|l|l|}
\hline $\mathbf{N}^{\mathbf{0}}$ & Settlement Name & Province and Village & Altitude \\
\hline 41 & Dikili Taş Mevkii Yerleşimi & Emirgazi/Eski Kışla & $1071 \mathrm{~m}$ \\
\hline 44 & Bolluca Höyük & Halkapınar/Yeşilyurt/Bolluca & $1362 \mathrm{~m}$ \\
\hline 45 & Kaleönü Yerleşimi & Halkapınar/İvriz & $1255 \mathrm{~m}$ \\
\hline 46 & Dibek Kalesi & Halkapınar/İvriz & $1601 \mathrm{~m}$ \\
\hline 47 & Avdallı Kalesi & Halkapınar/Yeşilyurt & $1601 \mathrm{~m}$ \\
\hline 48 & Avdallı Höyük & Halkapınar/Yeşilyurt & $1495 \mathrm{~m}$ \\
\hline 49 & Kapaklı Yerleşimi (Kalesi) & Halkapınar/Yeşilyurt & $1512 \mathrm{~m}$ \\
\hline 50 & Evaltı Yerleşimi & Halkapınar/İriz & $1177 \mathrm{~m}$ \\
\hline 51 & Gölbă̆ Yerleşimi & Halkapınar/İvriz & $1281 \mathrm{~m}$ \\
\hline 52 & Mindos Kalesi & Halkapınar/Kayasaray Köyü & $1759 \mathrm{~m}$ \\
\hline 53 & Karakaya & Halkapınar/Eskihisar/Gavurçukuru Mevkii & $1859 \mathrm{~m}$ \\
\hline 54 & Arısama Kalesi & Emirgazi/Eski Kışla & $1352 \mathrm{~m}$ \\
\hline 55 & Acıdere Höyük & Ereğli/Kuskuncuk & $1230 \mathrm{~m}$ \\
\hline
\end{tabular}

Emirgazi (Map 1) ${ }^{6}$. In 2015 the Halkapınar province, west and south of Emirgazi, and the southern area around the dry Lake Akgöl were investigated (Map 1). The settlement numbering system for the whole survey area has started in 2013 with Settlement $\mathrm{N}^{\mathrm{o}} 1$ and has since followed a successive numbering system. The first new settlement number for the 2015 season was $\mathrm{N}^{\circ} 44$ (Table 1). Twelve new sites were identified and surveyed in 2015 in addition to a site identified in 2014, $\mathrm{N}^{\mathrm{o}} 41$ Dikili Taş Mevkii Yerleșimi (Table 1) 7 .

Several methods were combined for the investigation of the surveyed areas such as seeking information from the local inhabitants, analyzing satellite images, and field walking. In most of the sites extensive field walking was not possible in the 2015 season due to high grass. Since 2013 all of the discovered and surveyed sites have been sketched, photographed, and GPS points taken. The diagnostic sherds are photographed and sketched on the site (Fig. 1). The selected pieces were drawn and photographed and put back on the spot where they were originally discovered.

During the 2015 survey season these villages were investigated:

Halkapınar province: Bahçelievler, Büyükdoğan, Çakıllar, Cumhuriyet, Dedeli, Delimahmutlu, Eskihisar, İvriz, Karayusuflu, Kayasaray, Körlü, Küsere, Osmanköseli, Seydifakıllı, Yassıkaya, Yayıkl1, Yeşilyurt.

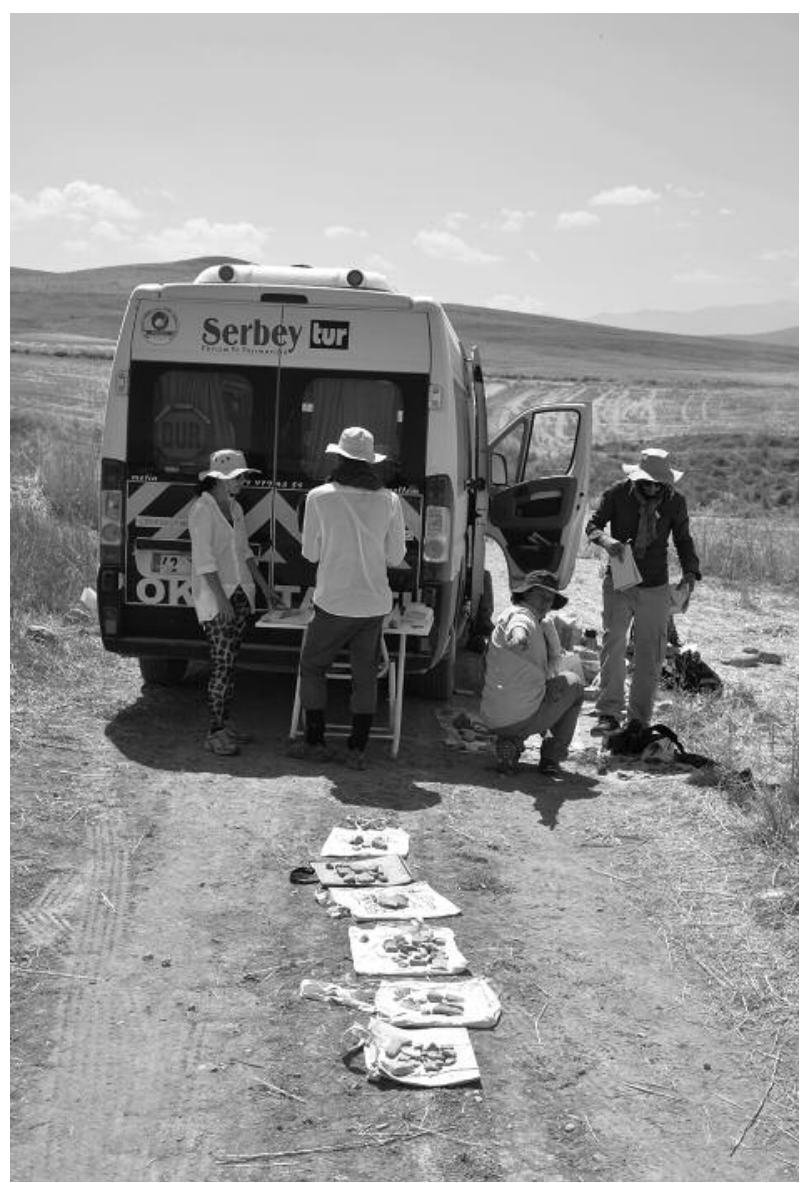

Fig. 1 : Documentation during the survey.

6) Maner 2015a; Maner forthcoming.

7) Dikili Taş Mevkii Yerleşimi is a settlement that was discovered and numbered in 2014 but could not be investigated properly due to bad weather conditions, hence the site was surveyed in 2015 and kept its number. 


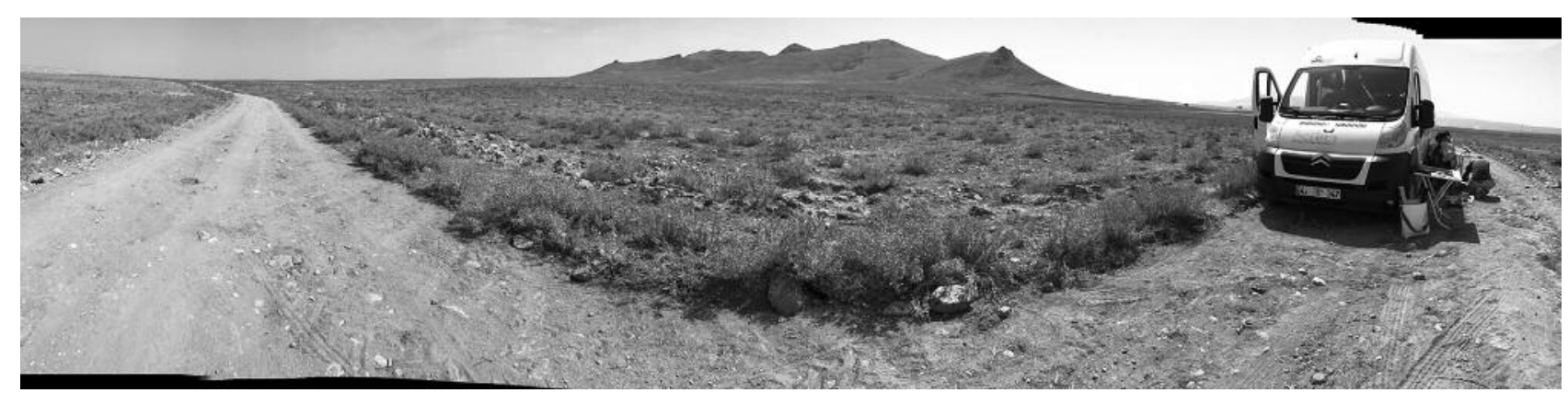

Fig. 2 : Dikili Taş Mevkii Yerleşimi (from west) with Mount Arısama in the back.

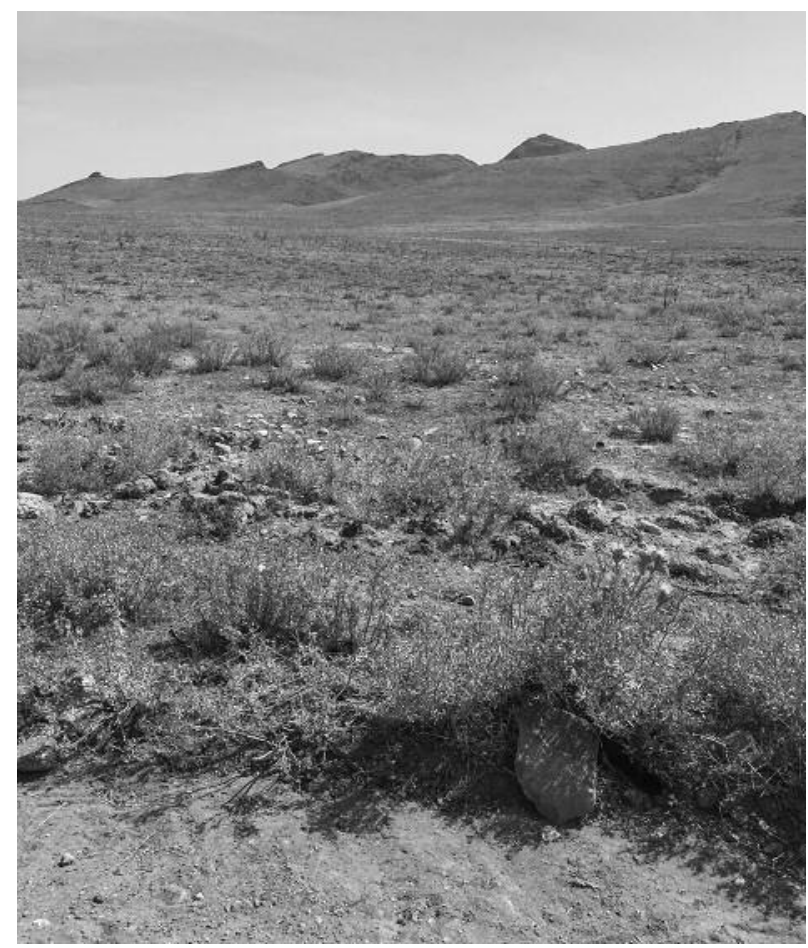

Fig. 3 : Dikili Taş Mevkii Yerleşimi (from north).

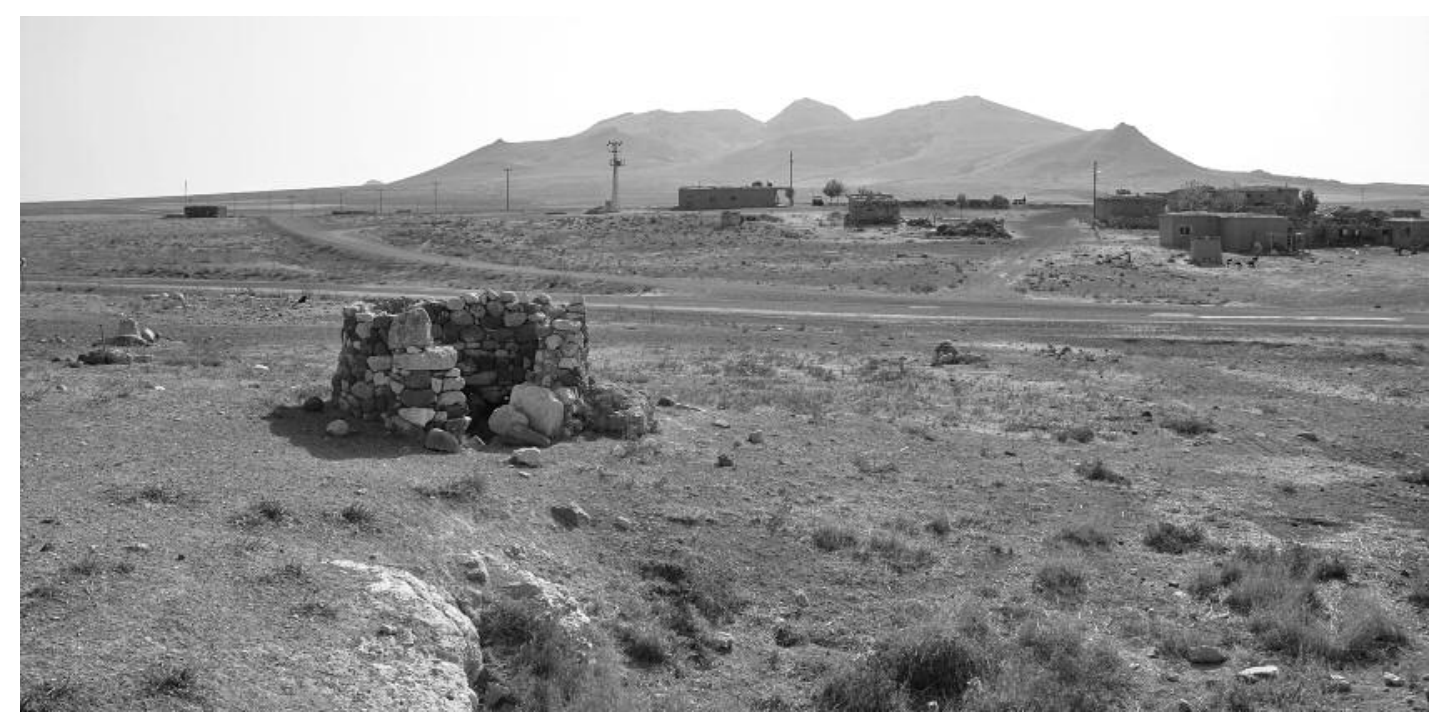

Fig. 4 : Eski Kışla quarter with Mount Arısama in the back. 

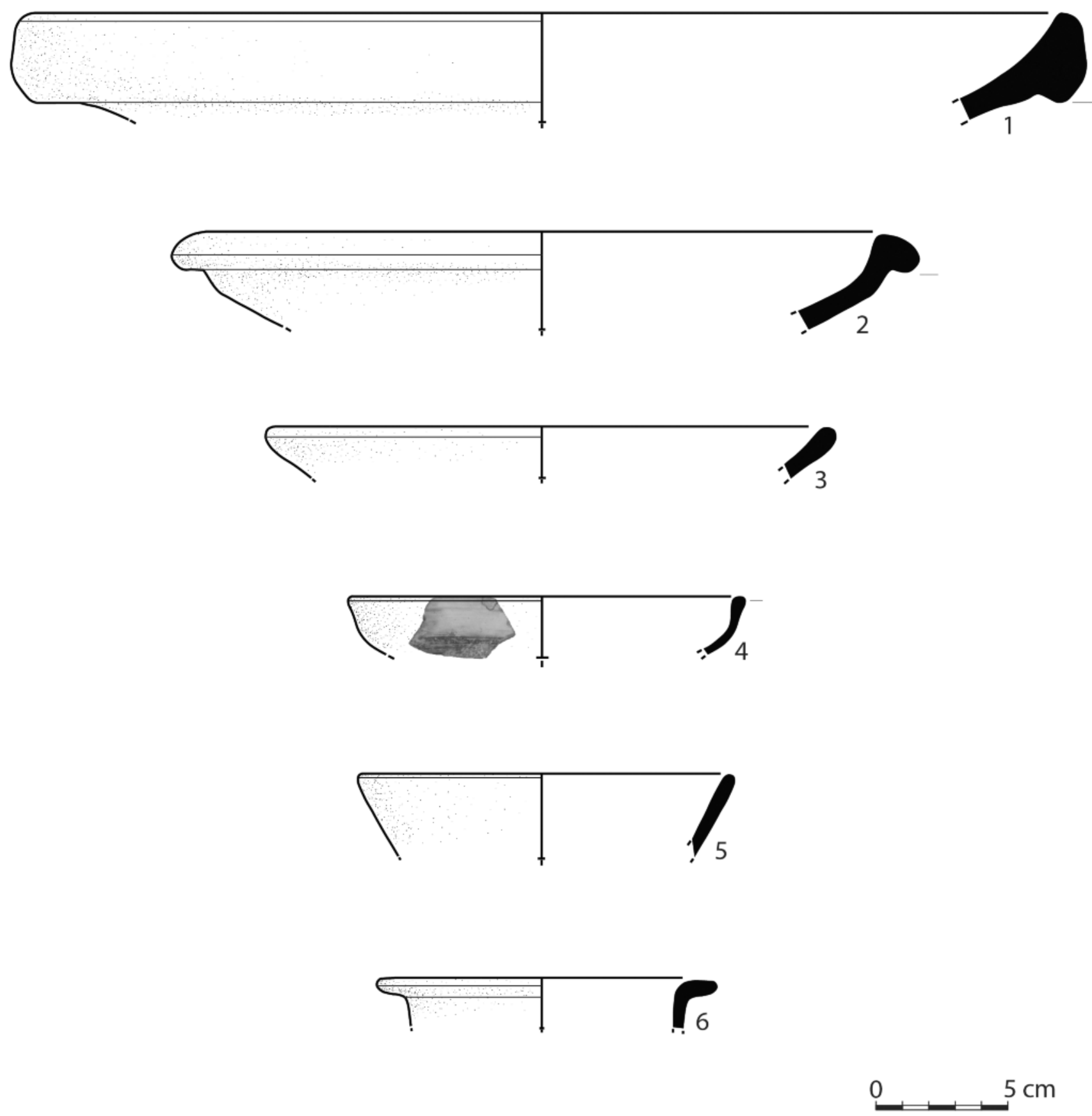

Fig. 5 : Pottery samples from Dikili Taş Mevkii Yerleşimi. 


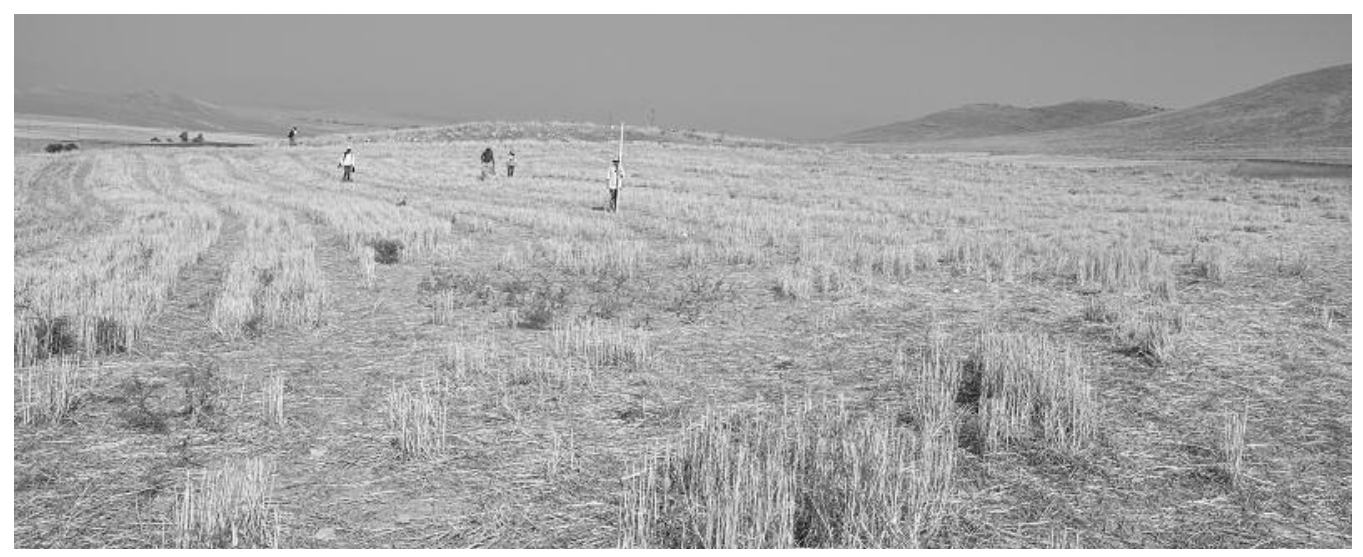

Fig. 6 : Bolluca Höyük (from north).

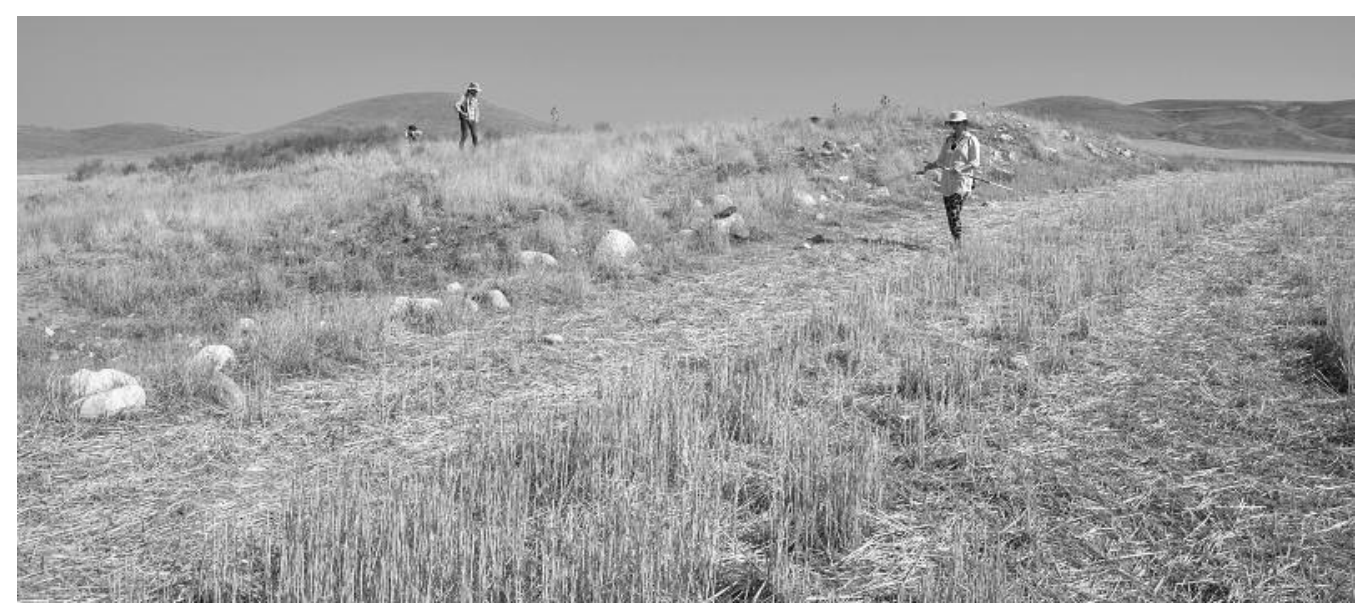

Fig. 7 : Foundation of a fortification (?) wall on the north slope of Bolluca Höyük.

Ereğli province: Kuskuncuk, Çayhan, Çakmak, Akgöl shore of Ereğli-Karapınar and the shore of the region between Ereğli-Karaman.

Emirgazi province: Dikili Taş Mevkii, Karaören, Iş1klar köyü.

\section{SURVEYED SITES IN 2015}

\section{Dikili Taş Mevkii Yerleşimi (Fig. 2-5)}

Dikili Taş Mevkii (Fig. 2-4) was discovered during the 2014 field season ${ }^{8}$. The site is $c a .3 .8 \mathrm{~km}$ north of Emirgazi and ca. $1 \mathrm{~km}$ east of Eski Kışla. In 2014 a short visit was paid to the site. However, since it was the end of the season, there wasn't enough time to start an extensive survey. The importance of this place is that a group of fragmentary mushroom-shaped altars with Luwian hieroglyphic inscriptions and a rectangular stone pool or altar, dating to the Hittite Imperial period in the reign of Tuthalija IV, were supposedly found here and also in Emirgazi ${ }^{9}$.

A villager, who is in his 60 's, remembered from his grandfather that these altars were standing in the fields north of Mount Arısama (also known as Kötü Dağ), the spot known as Dikili Taş Mevkii (Place of the Standing Stone). Dikili Taş Mevkii is part of the Eski Kışla quarter $1 \mathrm{~km}$ east of Emirgazi.

In 2015 Dikili Taş Mevkii was revisited and surveyed. A large region of $c a .1,5 \mathrm{~km}(\mathrm{~N}-\mathrm{S})$ and $0,7 \mathrm{~km}(\mathrm{E}-\mathrm{W})$ contains pottery (Fig. 5). The whole area is currently used as a field. No architecture or worked stone was discovered. Probably they were carried away to build the stone houses of Eski Kışla (Fig. 4). The houses were investigated for spolia but unfortunately none could be found. 

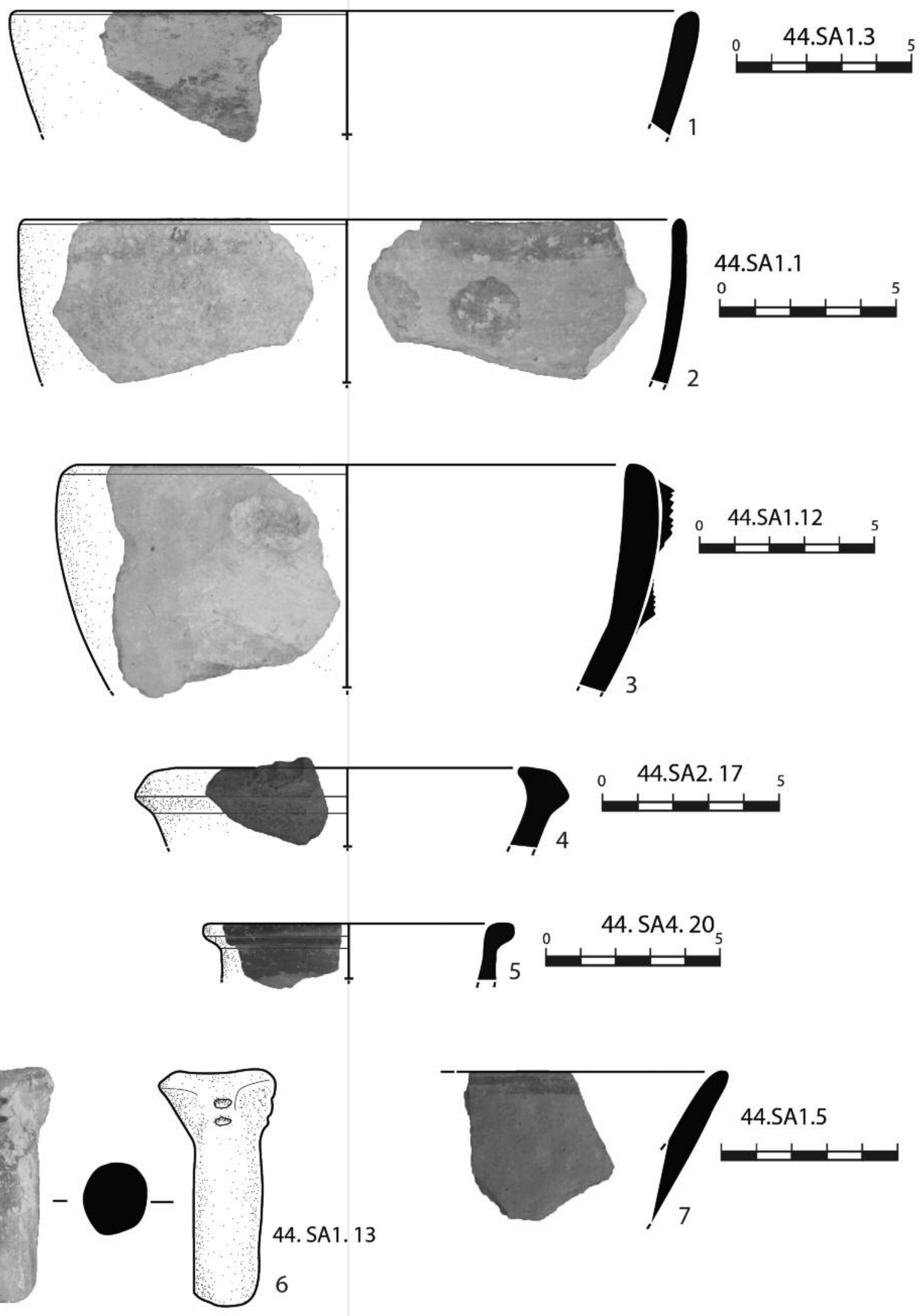

Fig. 8 : Pottery samples from Bolluca Höyük. 


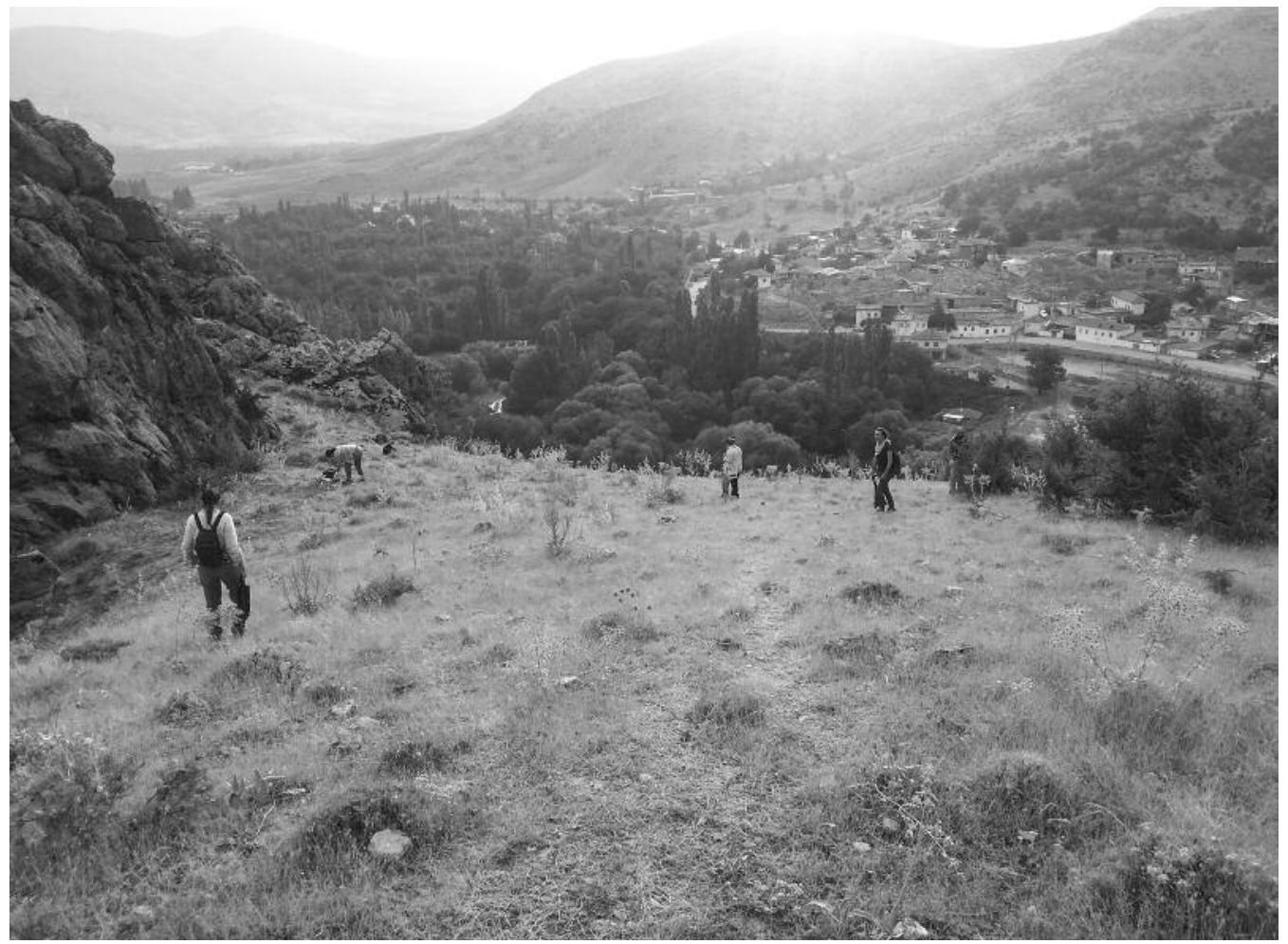

Fig. 9 : Kaleönü Yerleşimi.

The inscription on the Emirgazi stone altars mention Mount Šarpa ${ }^{10}$, which is worshipped and deified by the Hittites. Mout Šarpa is likely Mount Arısama ${ }^{11}$. Börker-Klähn assumes that the Hittite town Uda could be located at the place where the altars were discovered, she supports her argument that in the Hittite town Uda the Mountain Šarpa was worshipped ${ }^{12}$.

\section{Bolluca Höyük (Fig. 6-8)}

Bolluca Höyük is $3.6 \mathrm{~km}$ northwest of Yeniköy (also known as Bokluca or Bolluca) and $7.75 \mathrm{~km}$ northeast of Halkapınar. The shallow settlement mound is situated right on the west bank of a dried river and measures $c a .30 \mathrm{~m}(\mathrm{~N}-\mathrm{S})$ by $30 \mathrm{~m}(\mathrm{E}-\mathrm{W})$ (Fig. 6-7). The river, known as Bokluca or Bolluca Deresi, no longer flows and the river bed is used to plant wheat and barley. Also the höyük and its surroundings are used for agriculture. Pottery was observed on the höyük as well as around it in a diameter of $c a .100 \mathrm{~m}$. On the north and east slopes of the höyük a $15 \mathrm{~m}$ long part of a foundation of a wall (ca. 1.7-2 $\mathrm{m}$ thick) is preserved, which is likely part of a fortification wall. The wall is built of medium sized slightly worked stones which are probably from the river bed. Among the diagnostic pottery sherds were Chalcolthic, Early - Middle - Late Bronze, and Iron Age (Fig. 8). Across the site on the eastern bank of the dried river bed is supposedly a second settlement. This was indicated to us by the villagers, but only three pieces of non-diagnostic sherds were found, because of the dry summer, dusty soil and also that the field was just plowed before our arrival. The place is of interest because apparently a Middle Bronze Age foundation peg and a Hittite Weather God bronze figurine were found here, which are now in a private collection though registered in the Ereğli Museum ${ }^{13}$.

\section{Kaleönü Yerleşimi (İvriz) (Fig. 9-10)}

This slope settlement was discovered during a field visit with the museum director Mr. Mahmut Altuncan in 2011. The pottery from the top had fallen down to the narrow path that leads to Ambarderesi. In 2015, during the detailed investigation of İvriz, this site was surveyed as well. Known by

10) Hawkins 1995: 86-102.

11) Personal communication, David Hawkins.

12) Börker-Klähn 2007: 93-95.

13) Publication forthcoming. 


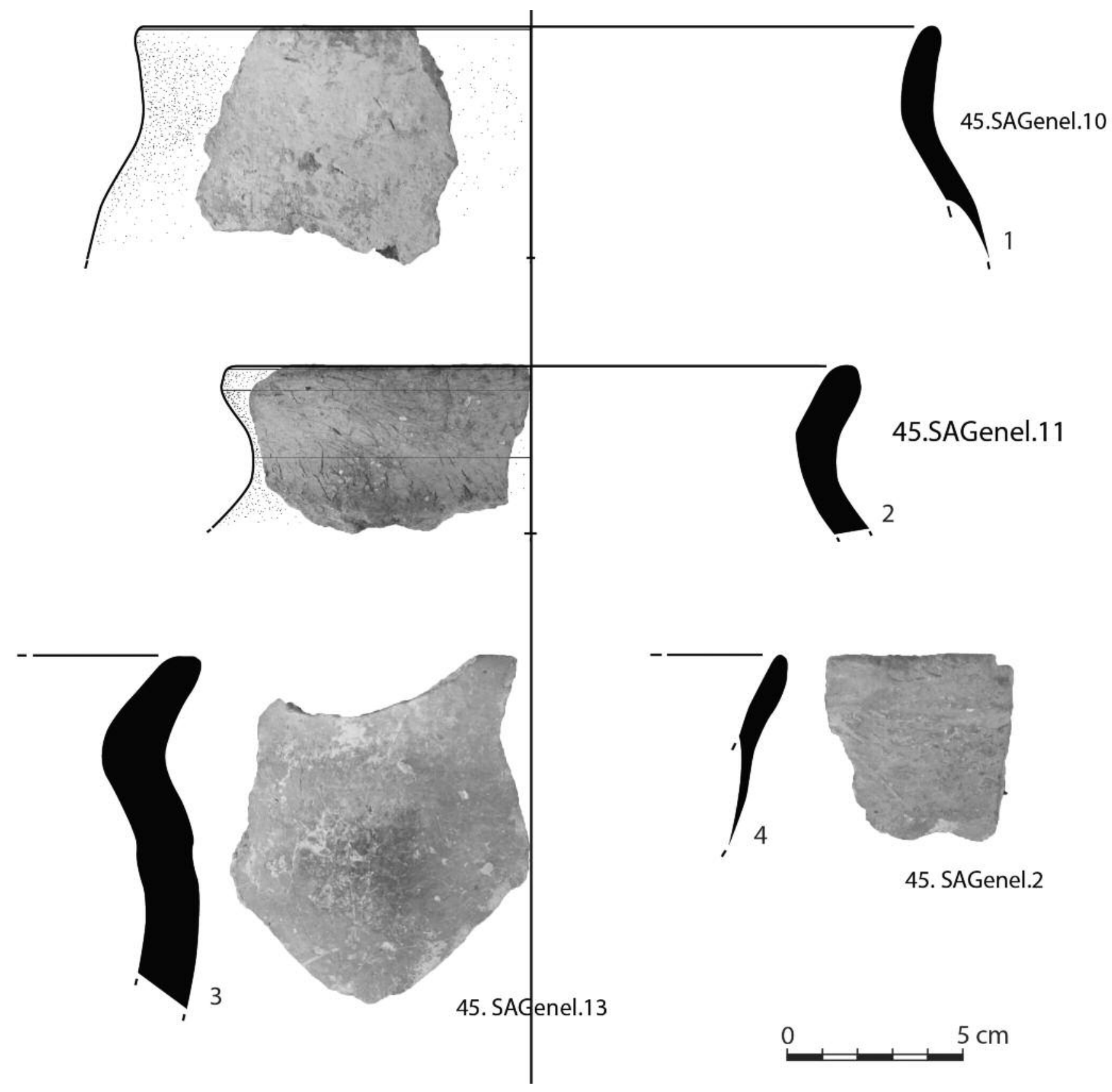

Fig. 10 : Pottery samples from Kaleönü Yerleșimi.

locals as Kaleönü, the site is $2.7 \mathrm{~km}$ south of İvriz and $0.3 \mathrm{~km}$ west of the İvriz relief on a hill at $c a$. 1,255 MASL (Fig. 9). Pottery is spread over an area of $c a .41 \mathrm{~m}(\mathrm{~N}-\mathrm{S})$ by $46 \mathrm{~m}(\mathrm{E}-\mathrm{W})$. Sherds were distribued on the western slope and accumulated on the top of the hill between two rock outcrops. No architectural remains were observed. Three obsidian blades in the Ereğli Museum are said to come from here. Among the pottery were sherds from the Chalcolithic, Early Bronze Age and Iron Age (Fig. 10).

\section{Dibek Kalesi (Fig. 11-12)}

The project's investigation of the northern slopes of the Taurus Mountains within the district borders of the Halkapınar province has led to a better understanding of the importance of the mountains for the protection of the Konya plain, which will be explained in the conclusion in detail. Dibek Kalesi (Fig. 11) is $3.36 \mathrm{~km}$ southeast of İvriz and $2.7 \mathrm{~km}$ from Halkapınar and is located on a very important strategic position, controlling on one side the exit northward down to 


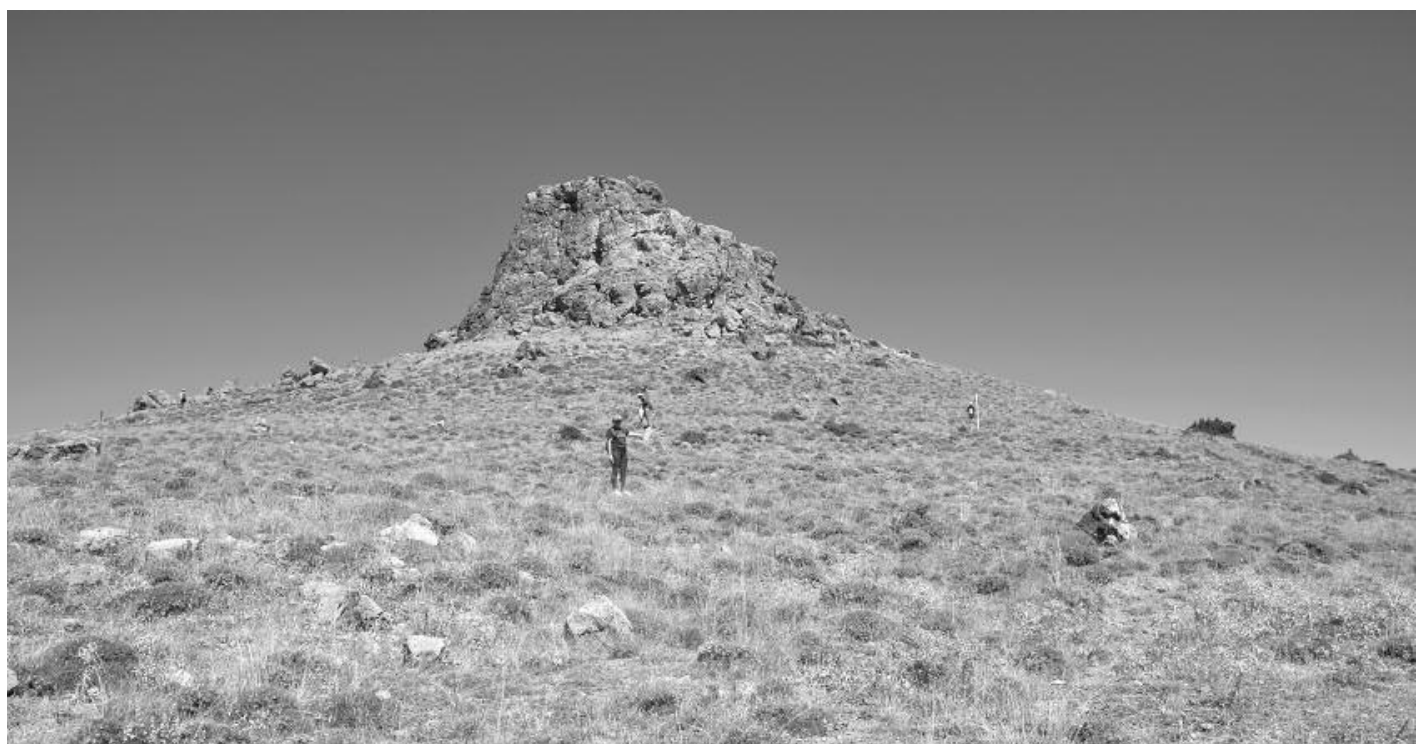

Fig. 11 : Dibek Kalesi.

the plain and on the other the Taurus Mountains and road networks south to the Mediterranean. The name of the castle, Dibek (mortar in english), was given by the locals because the shape of the castle is reminiscent of a mortar. The castle is built at 1803 MASL and is likely a control fort located on a road network leading down to Mersin via Çamliyayla (locally known also as Namrun Yaylasi) to the south. This road is still used by locals today.

The fortress is built around a summit. A dirt road north of the village of İvriz, which was made by the muhtar of İvriz for the shepherds, leads to the slopes of the castle. The northwestern and western slopes of Dibek Kalesi are dangerous and steep, whereas the southern and eastern slopes are gentle. Building stones from the fortification wall of the fortress are scattered all over the slopes. Tall dry plants were covering the remains of foundations. Specifically on the southwestern slopes, foundations of walls are visible. Due to the tall dry grass that covered the ground it was almost impossible to find pottery sherds. Among the observed sherds were those of the Middle and Late Bronze Age, Iron Age and Roman period (Fig. 12).

\section{Avdallı Kalesi (Fig. 13)}

Avdall1 Kalesi (Fig. 13) is $2.4 \mathrm{~km}$ southwest of Yeşilyurt and $7.8 \mathrm{~km}$ northeast of Halkapınar. Avdallı Kalesi is built around a natural hilltop at a height of ca. 1601 MASL. The castle is not really preserved, however villagers attest that until recently fortification walls were visible that were destroyed by snow storms and rain. Foundations ( $c a$. $0.5-0.7 \mathrm{~m}$ wide) of walls are visible between high grass on the south and southeast slopes, one course being preserved. The size of the castle could not really be determined. However, building stones cover mainly the southern and southeastern slope, which is an area $c a .130 \mathrm{~m}$ (N-S) by $200 \mathrm{~m}(\mathrm{E}-\mathrm{W})$. The length of the foundations could not be determined due to high dry grass. But it is clear that specifically the foundations on the southern slope belong to a larger building. The foundations are Cycploean ${ }^{14}$, made of medium sized stones. Due to high dry grass only three undiagnostic sherds were found, hence it is difficult to date these foundations. This masonary technique was used from Early Bronze until the Roman Period. Avdalli Kalesi leads to road networks in the Taurus Mountains, which lead to the yaylas of Mersin and from there down to the Mediterranean. These paths are still used today. Avdallı Kalesi is ca. $6.7 \mathrm{~km}$ notheast of Dibek Kalesi $\left(\mathrm{N}^{\circ} 46\right)$, which is visible from this site.

\section{Avdallı Höyük (Fig. 14)}

Avdallı Höyük (Fig. 14) is just north of the Yeşilyurt cemetery and $\mathrm{ca}$. $2.1 \mathrm{~km}$ southeast of Yeşilyurt. The höyük is low and measures $c a .82 \mathrm{~m}$ $(\mathrm{N}-\mathrm{S})$ by $49 \mathrm{~m}(\mathrm{E}-\mathrm{W})$. The whole höyük is used for stones.

14) Cyclopean masonery means that roughly shaped bolders are placed on top of each other and interstices are filled with smaller 

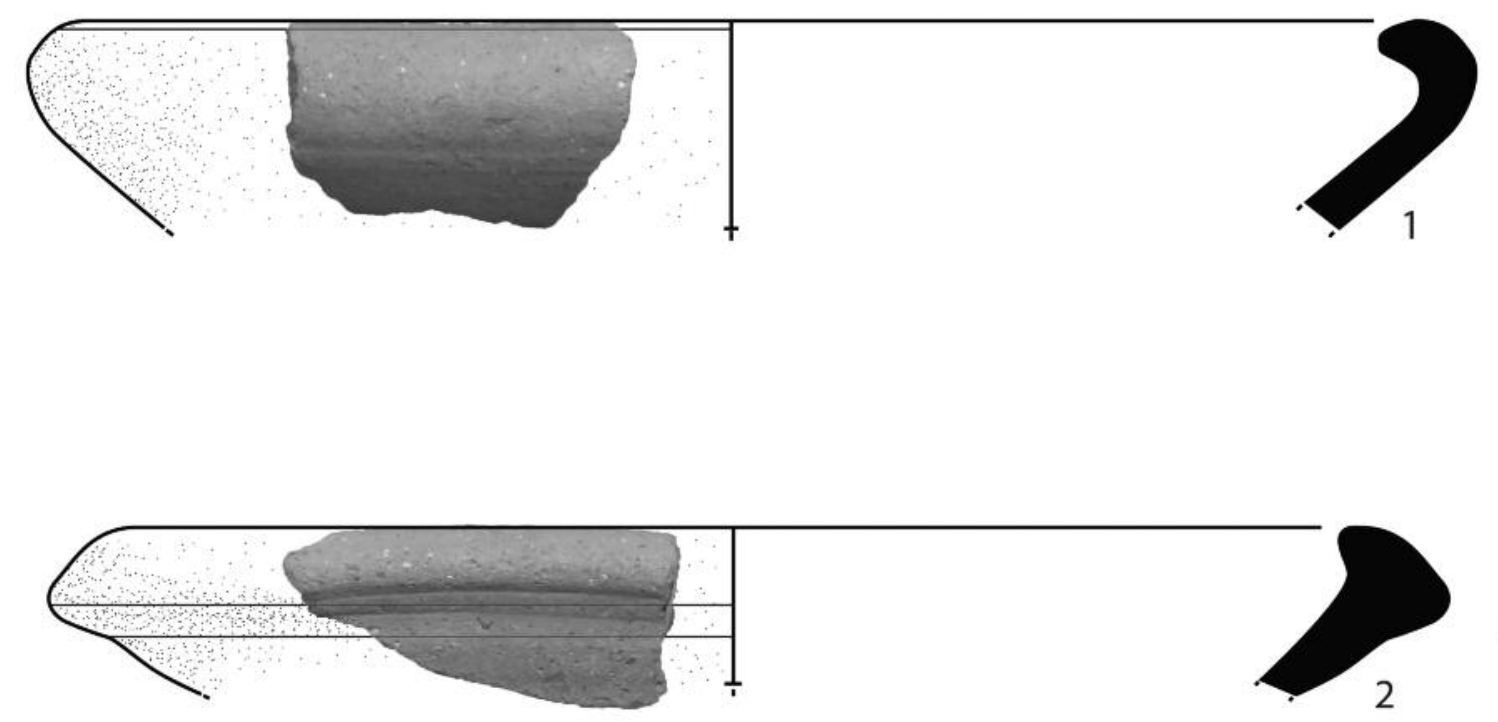

46.SA 1.2
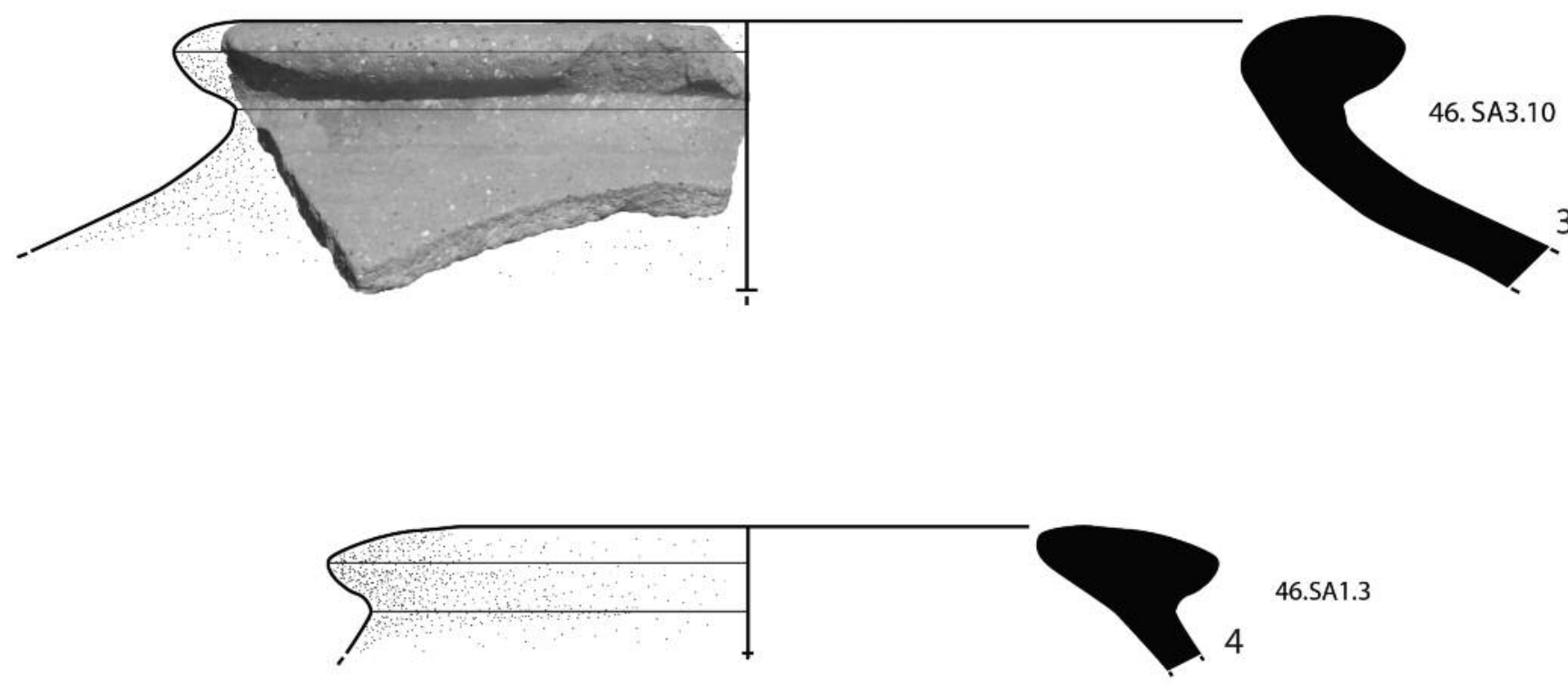

46.SA1.3
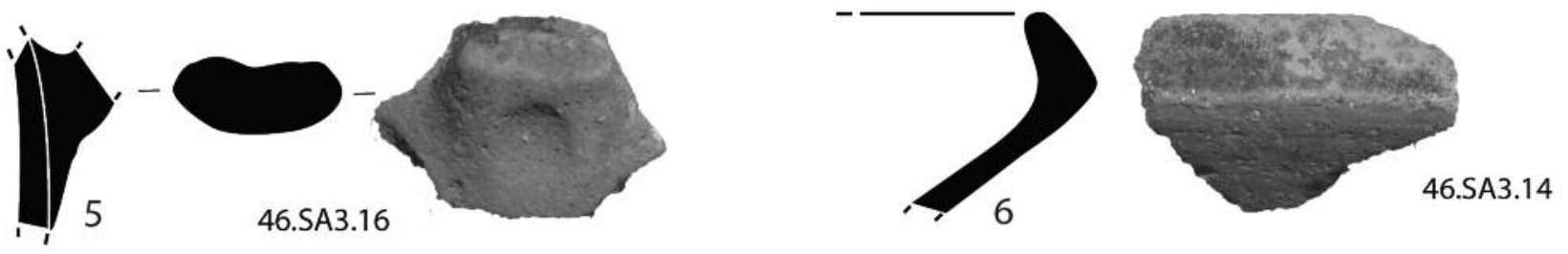

0 $5 \mathrm{~cm}$

Fig. 12 : Pottery samples from Dibek Kalesi. 


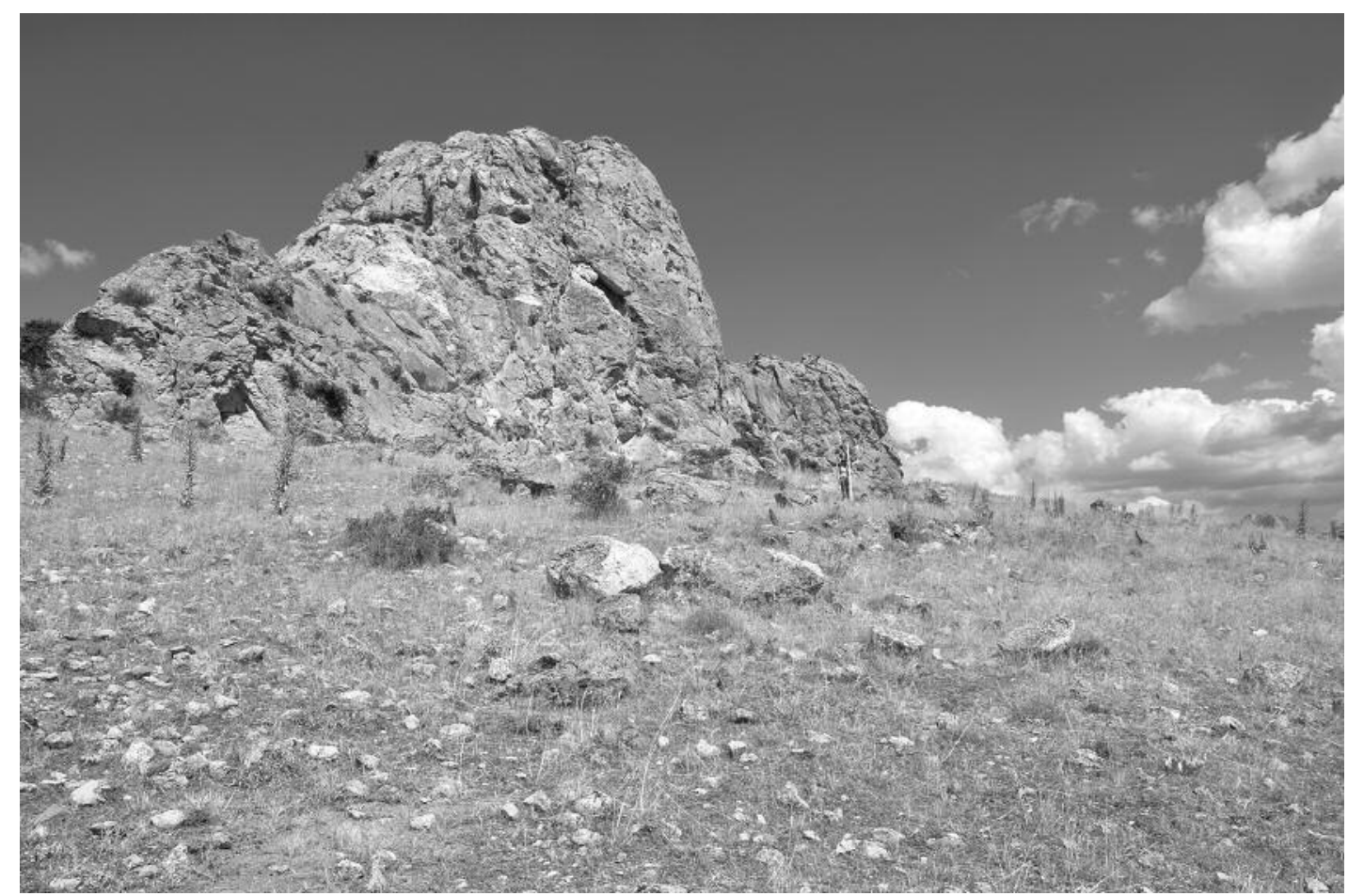

Fig. 13 : Avdallı Kalesi.

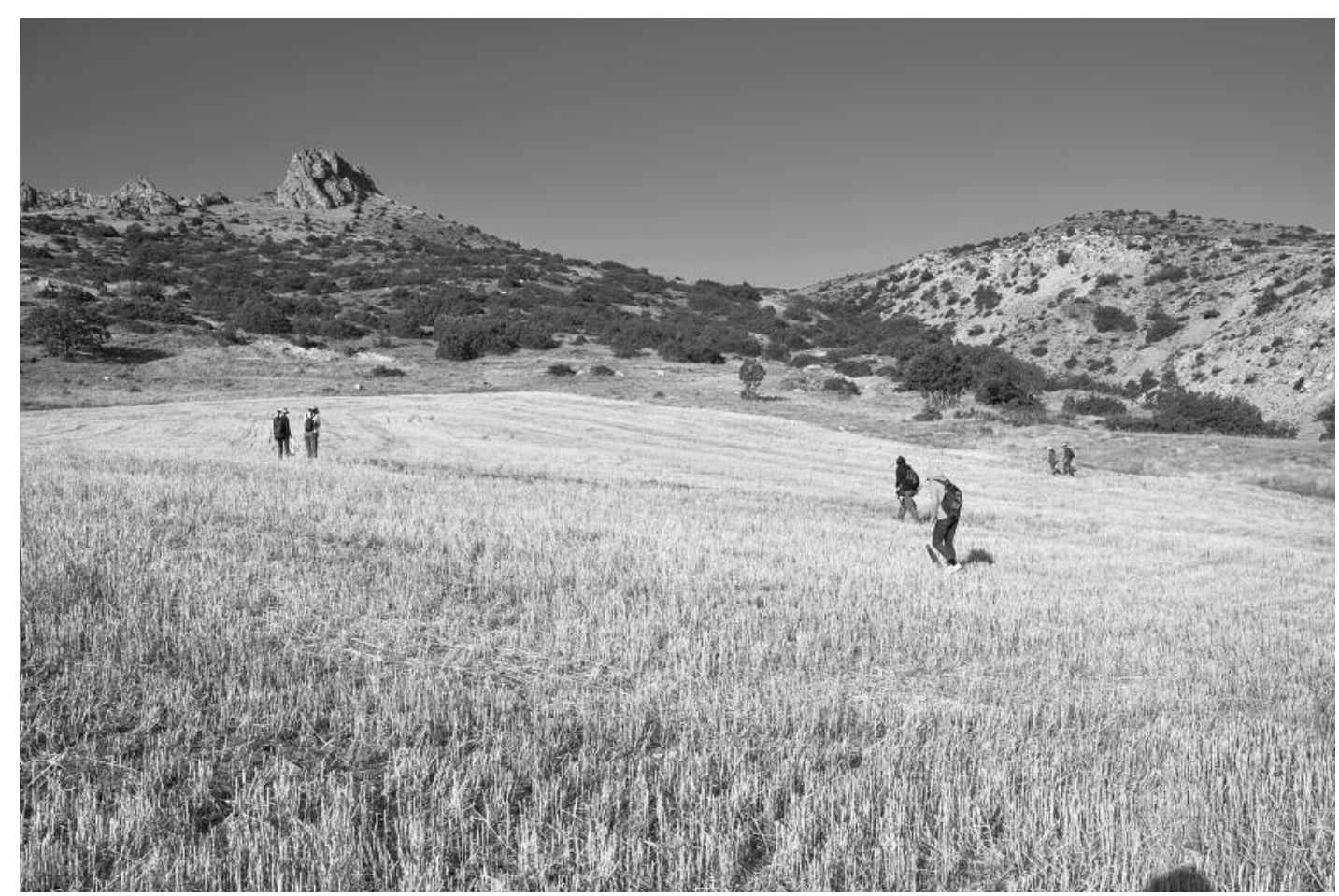

Fig. 14 : Avdallı Höyük. 


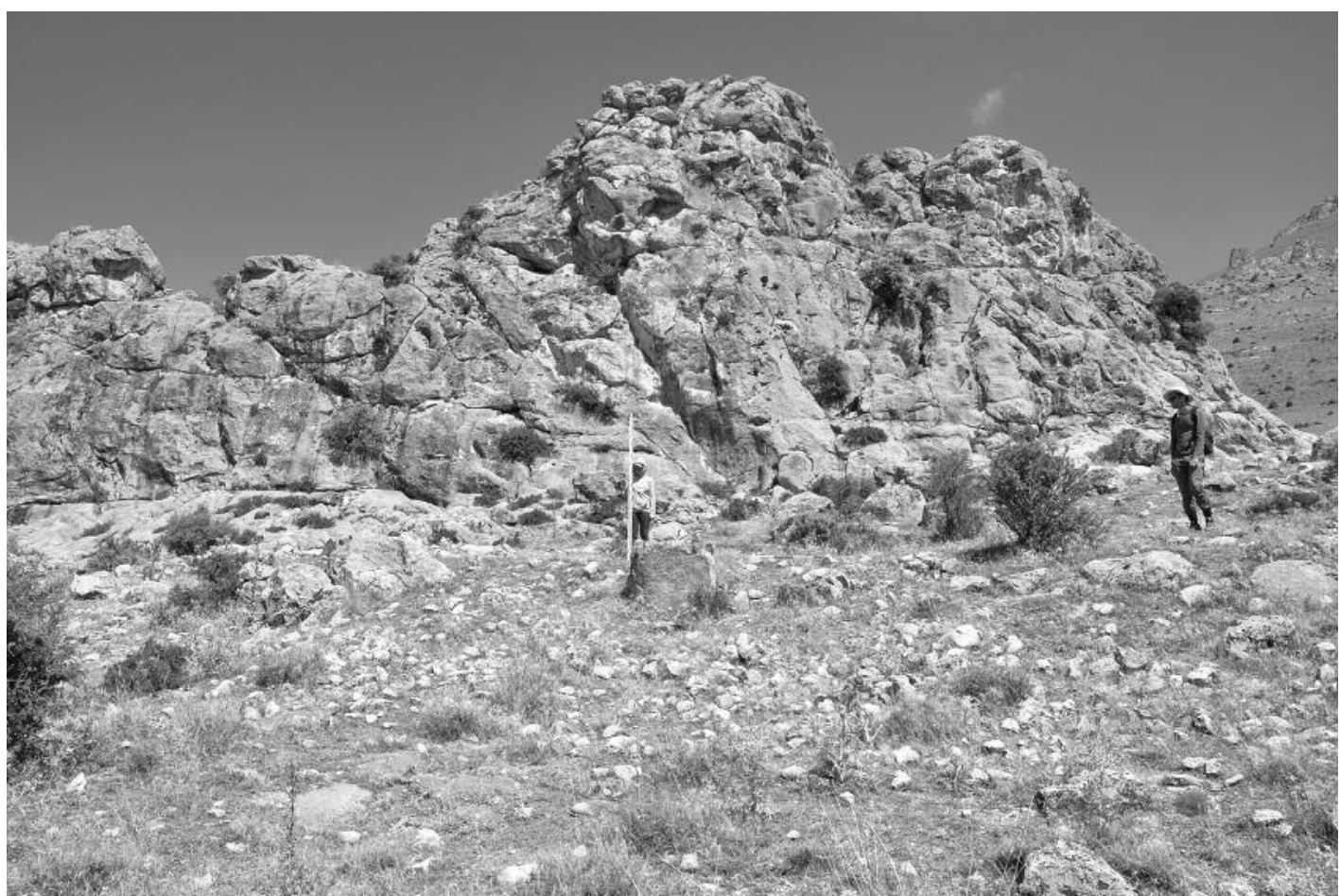

Fig. 15 : Kapaklı Yerleşimi (Kalesi).
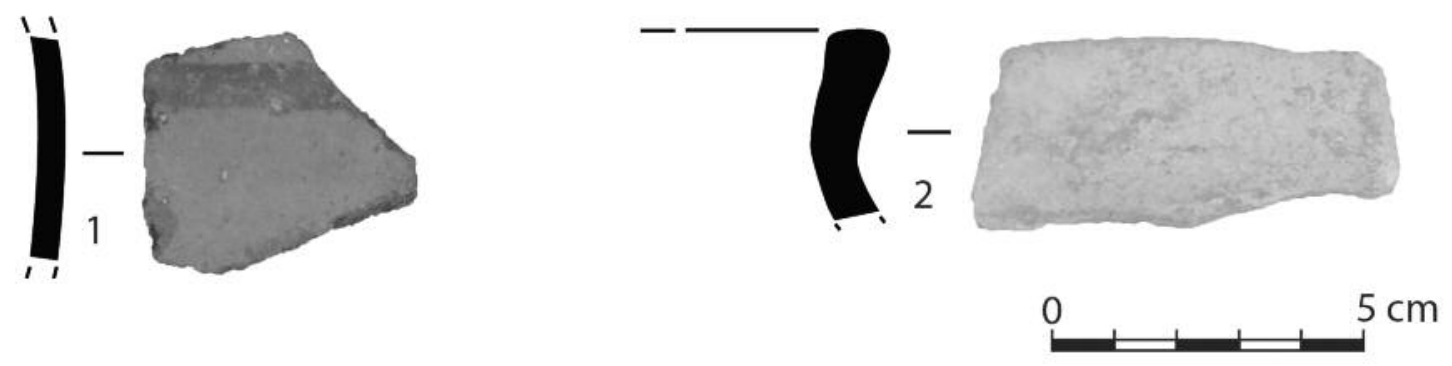

Fig. 16 : Pottery samples from Kapaklı Yerleşimi (Kalesi).

agricultural purposes. Due to dense covering of crops only a few sherds were discovered. These probably date to the Early Bronze Age.

\section{Kapaklı Yerleşimi (Kalesi) (Fig. 15-16)}

Remains of a castle could be located at a site known by locals as Kapakl1 Kalesi (Fig. 15). This castle is located on a hilltop that runs parallel to the Taurus Mountains and is north of Myndos Kalesi (castle) in Kayasaray. The spot controls the pass from the Konya Plain down to the HalkapinarUlukışla road and the Taurus Mountains. Not much of Kapaklı castle is preserved. The castle was built around the summit. Hundreds of small building stones are scattered on the southern slope. A few foundations are still visible. Among the pottery are
Middle (?) and Late Bronze Age, Iron Age and Roman sherds (Fig. 16).

\section{0. İvriz Evaltı Mevkii Yerleşmesi (Fig. 17-18)}

İvriz, the village and also the area where the Neo-Hittite relief is situated, underwent several modern construction phases specifically after the 1940's. The construction of the water channels around the Ivvriz monument, the construction of the İvriz water dam and also the area north of the monument, which is leveled and used as a picnic area, have changed the natural geography. Due to all of this construction work it is almost impossible to detect ancient pottery around the relief area. A second handicap is that the area around the monument and also the southern part of the village have been 


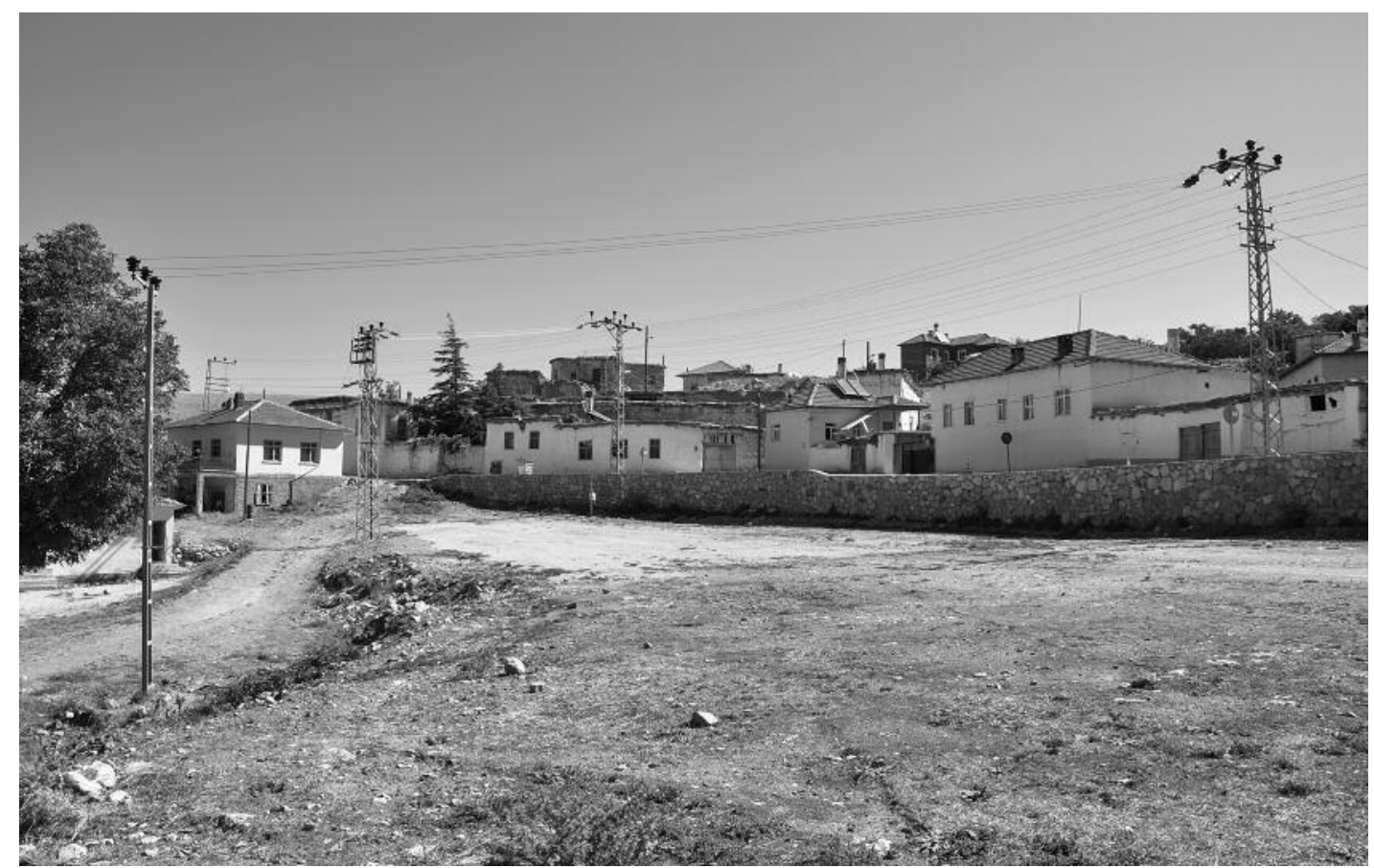

Fig. 17 : İvriz Evaltı Mevkii Yerleşmesi.

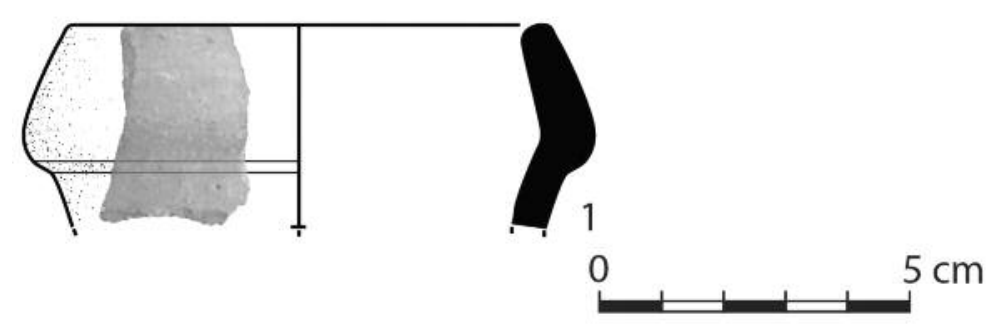

Fig. 18 : Pottery sample from İvriz Evaltı Mevkii Yerleşmesi.

flooded several times over a long time span. Locals pointed out that the last big flood in the 1960's, coming from the eastern slopes of the Taurus Mountains, destroyed the southern part of the village. Locals indicated that at a minimum of twice every hundred years, floods destroyed parts of the village.

During the investigation in the village itself almost no ancient pottery was found. This is probably also due to the fact that because of these floods, the ancient settlements (if there were any) are covered with soil and rubble from these floods.

The survey in the village of İvriz revealed a new site with ancient pottery. The location is known as İvriz Evalt1 Mevkii (Fig. 17), located $2.7 \mathrm{~km}$ south of Halkapınar and just $8 \mathrm{~m}$ east of the NeoHittite relief. The southern part of the site is used for sewage facilities of the municipality. The pottery distribution in İvriz Evaltı Mevkii Yerleşmesi covers $c a$. an area of $97 \mathrm{~m}(\mathrm{~N}-\mathrm{S})$ by $38 \mathrm{~m}(\mathrm{E}-\mathrm{W})$. The pottery shows a wide range from Middle - Late BronzeAge, Iron Age, Roman, and green glazed probably of the Byzantine and Ottoman periods (Fig. 18). No architectural remains were found.

\section{Gölbağ Yerleşimi (Fig. 19-20)}

During the survey the hilltops around İvriz were investigated as well. Foundations of a building 0.54 $\mathrm{km}$ southeast of the İvriz village were discovered (Fig. 19-20). The place is known as Gölbağı Mevkii by the locals. A road up to the hill just on the left side of the entrance to the small bridge over the İvriz stream leads to a large building foundation, the full extent of which could not be determined. Probably the stones of the foundations and the upper wall were used to built the village houses of İviz. The foundations of the building made of boulders ca. 40-80 cm long and around 15-30 m wide. The 


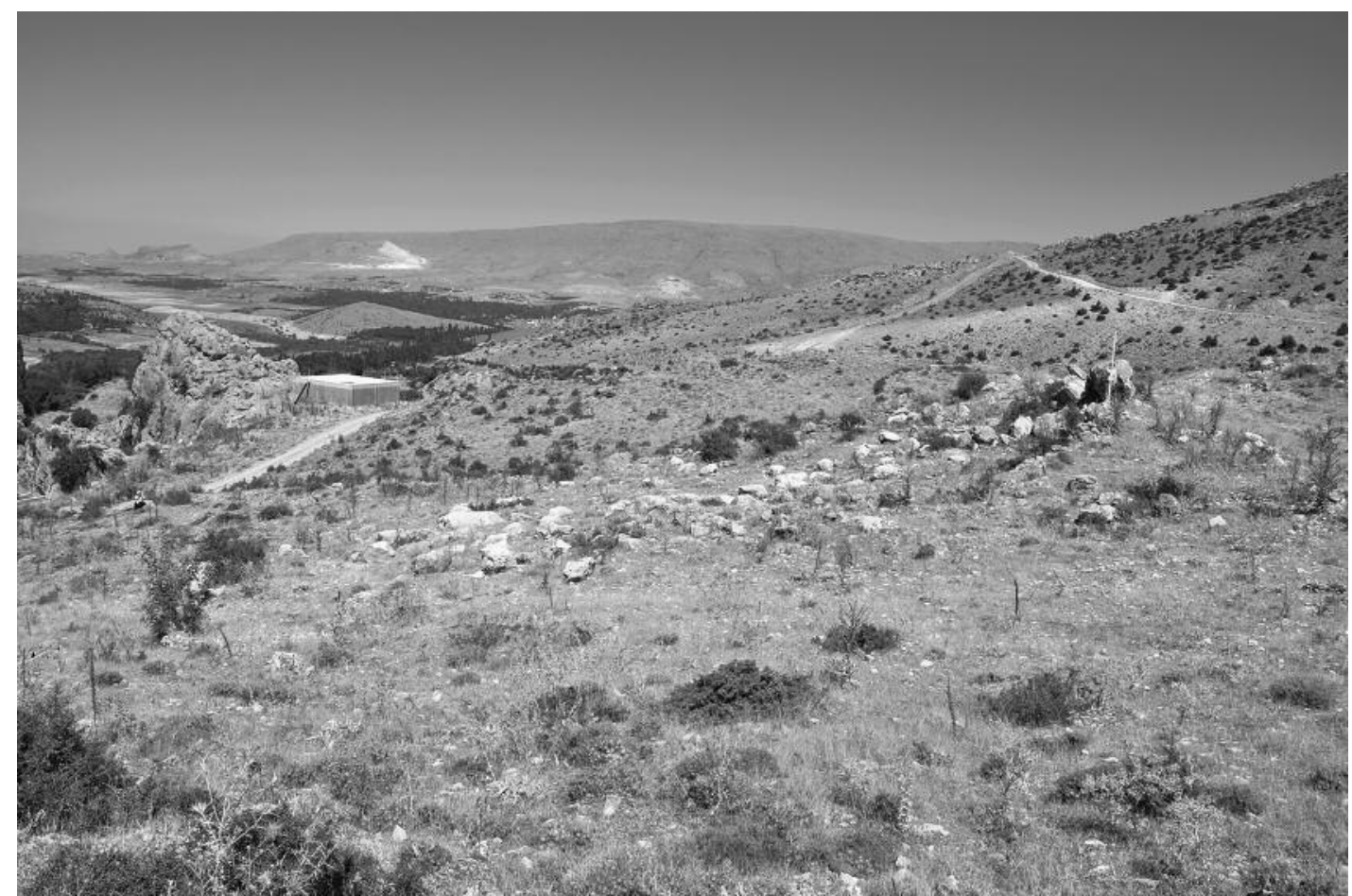

Fig. 19 : Gölbă̆ Yerleşimi.

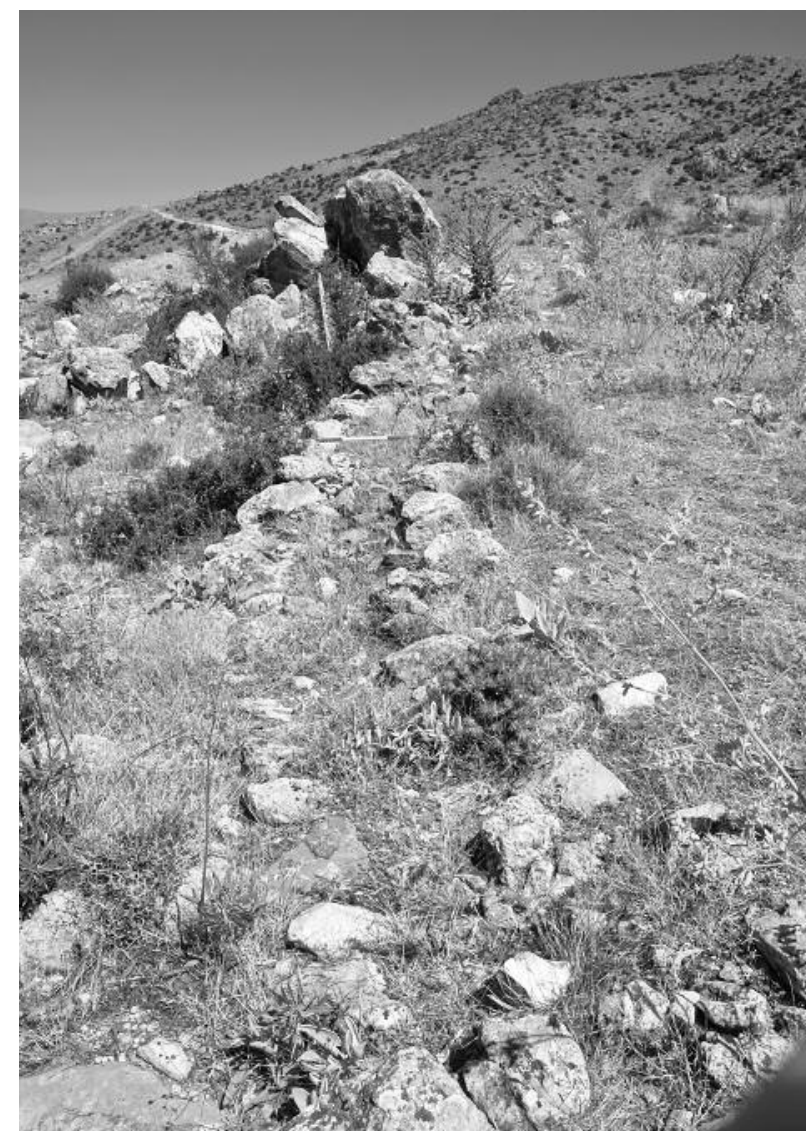

Fig. 20 : Stone wall in Gölbağ Yerleşimi. cyclopean wall is preserved on the south side in some parts up to two courses, and there is no indication of mortar between the stones. The preserved foundation indicate a building at least $c a .70 \mathrm{~m}(\mathrm{~W}-$ E) by $78 \mathrm{~m}(\mathrm{~S}-\mathrm{N})$. As the foundations break off, it can be assumed that it was once much larger. Dibek Kalesi is visible from here. Gölbașı Mevkii Yerleșimi must have also been a castle, controlling the descend from the Taurus Mountains down to the plain. Due to thorny vegetation, which covered the whole surface, no pottery was found.

\section{Mindos Kalesi (Fig. 21)}

Mindos Kalesi (Fig. 21), which is also known as Kale-i Mindos by locals, is located in Kayasaray village (also known as Kalesaray by locals) $8.9 \mathrm{~km}$ east of Halkapinar. The castle is $0.15 \mathrm{~km}$ east of the village. The castle is built around a high outcrop (1750 MASL). The original village of Kayasaray was built on the southern slopes of this outcrop. According to locals, in the 1980's boulders started to fall down from the peak, houses were destroyed, and villagers were killed. The village was evacuated to the place where it is today, southwest of the peak. However, still today a few houses are inhabited on the southern side of the peak. The survey around the outcrop yielded no pottery. As the village was built 


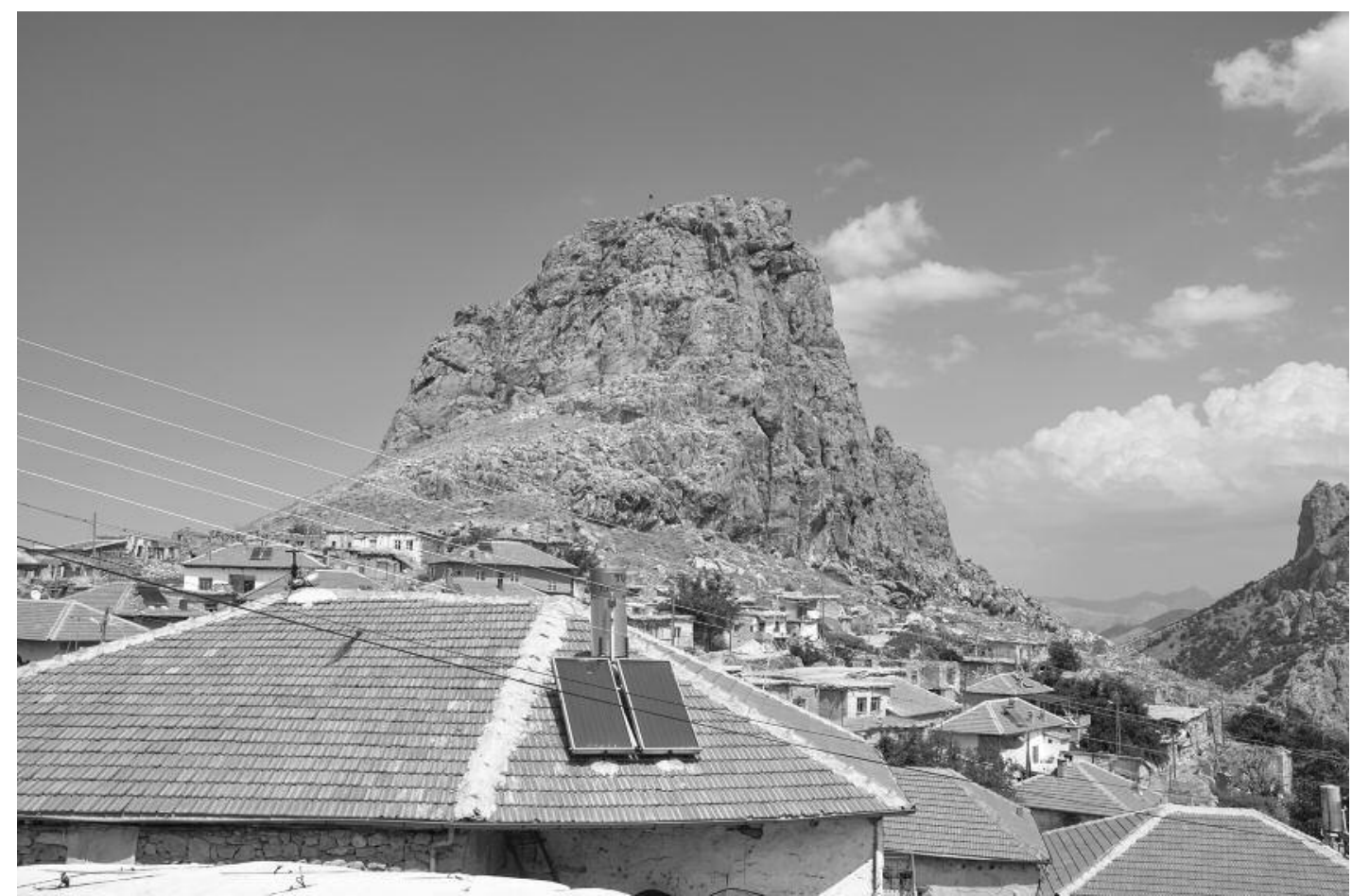

Fig. 21 : Mindos Kalesi.

on the ancient castle and the village was destroyed by stone bolders, there seems to be no ancient architecture preserved.

Kalesaray has a very important strategic location. It is on a pass from Mersin down to the Konya Plain. According to the locals, until fifteen years ago camel caravans and nomads were passing through Kayasaray coming down from the Taurus Mountains. They rested in Kayasaray before preceding further down to the Konya Plain. The pass from Kayasaray leads south over the Taurus Mountains to the pastures of Çamliyayla Mersin and from there down to Mersin and the Mediterranean coast. Even today these routes are used by locals to go down to Mersin.

\section{Karakaya (Fig. 22)}

This location, which is known as Gavurçukuru Mevkii by locals, was shown to us by the muhtar of Eskihisar. The location is $5.3 \mathrm{~km}$ southeast of Halkapinar and $1.4 \mathrm{~km}$ southwest of Eskihisar. The castle, which is known as Karakaya, is built on top of a hill (Fig. 22) that controls like all the other castles the route through the Taurus Moutains and down to the Konya plain. Leveled bedrocks and a few building stones on the hilltop are the only remains of the castle. Only three undiagnostic sherds were found, hence it is not possible to say when it was built.
It can be assumed that it is part of the castle chain on the Taurus Mountains to control the trade routes from the Mediterranean into the Konya Plain.

\section{Arısama Kalesi (Fig. 23-24)}

Arisama castle (Fig. 23-24) is built on the summit (1402 MASL) of Mount Arisama (also known as Kötü Dağ among locals). The castle is $c a .3 .3 \mathrm{~km}$ northeast of Emirgazi and ca. $5.2 \mathrm{~km}$ northwest of Belkaya. Dikili Taş Mevkii Yerleşmesi is located down at the eastern slope of this mountain (Settlement $\mathrm{N}^{\mathrm{o}}$ 41). A dirt road leads from the eastern side of the mountain to the southern slopes of the peak, which is covered with thousands of building stones fallen down from the top. This road leads down to Emirgazi, which is $c a .3 \mathrm{~km}$ southwest from here. To climb up to the peak is very difficult as it is steep and the ground is covered with a layer of building stones. Also the season of 2015 was very dry and the soil was very loose and crumbling, which made the hike probably more difficult than it would otherwise be.

Arisama castle measures $c a .125 \mathrm{~m}(\mathrm{~N}-\mathrm{S})$ by 92 $\mathrm{m}(\mathrm{E}-\mathrm{W})$. Fortification walls and towers are visible from the slopes of the mountain. The castle consists of a fortification wall which encircles the peak of the mountain. This wall is supported with rectangular towers. Inside the walls the ruins of a building are visible. The fortification walls and ruins mainly 


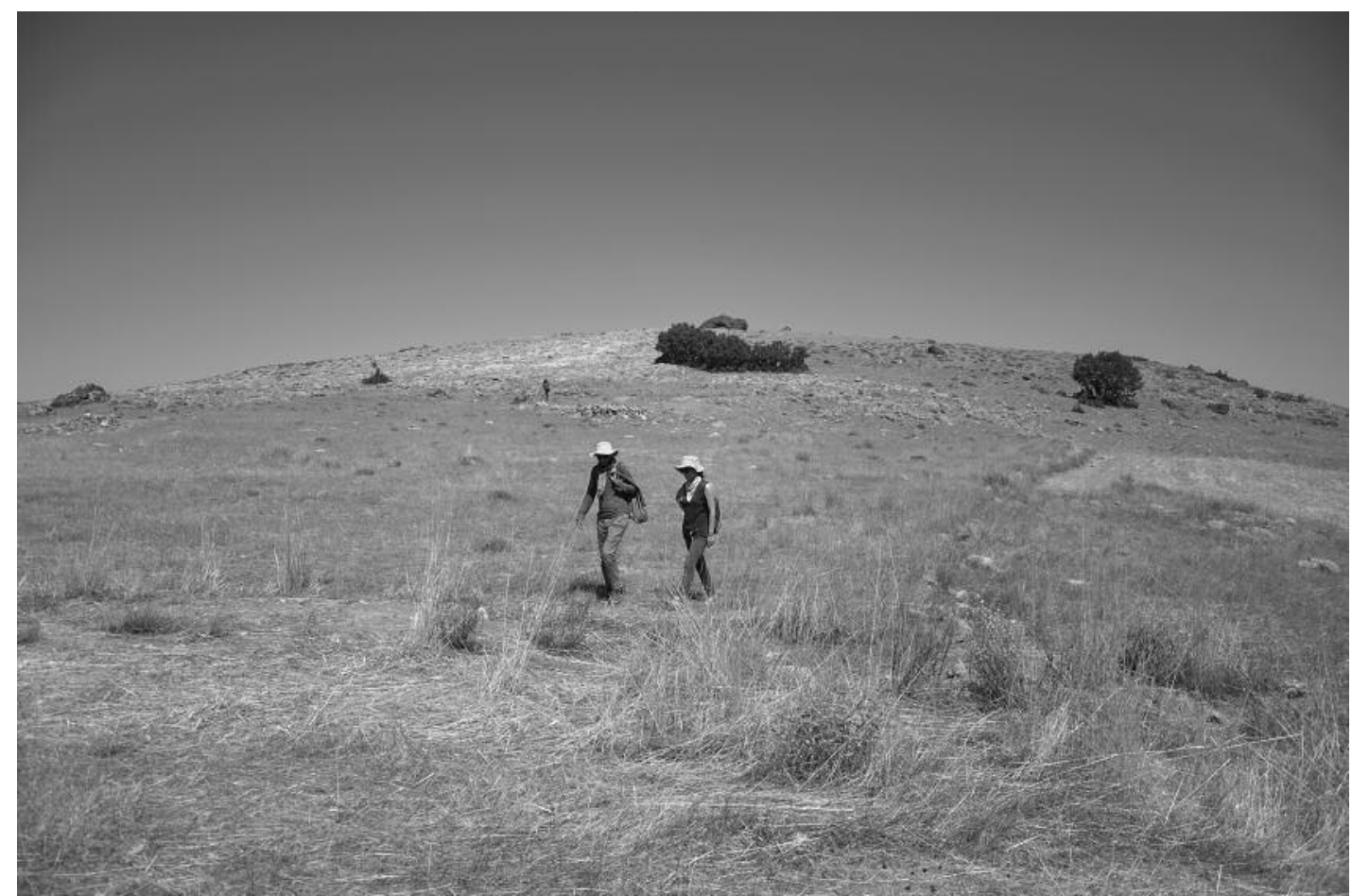

Fig. 22 : Karakaya.

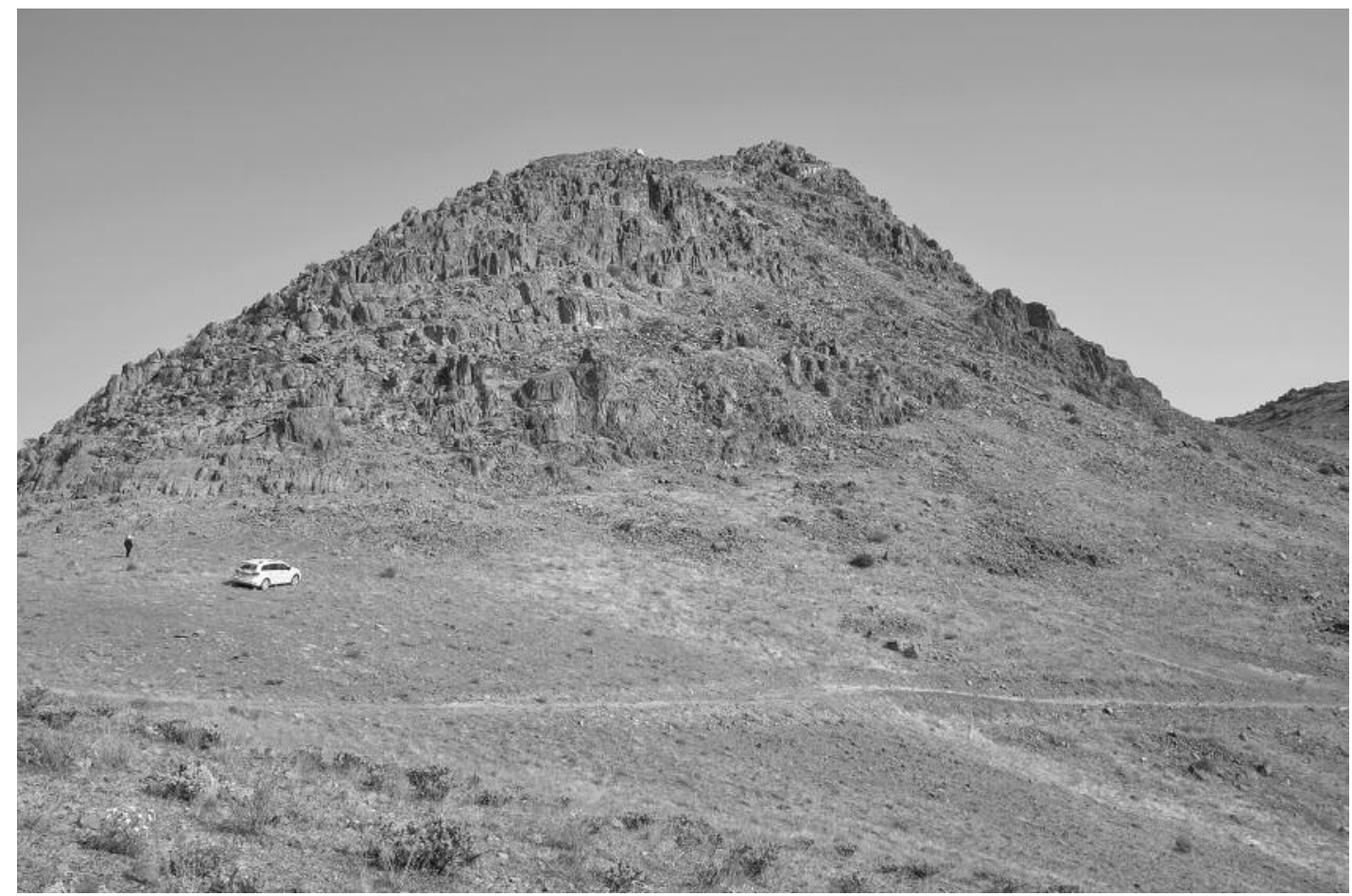

Fig. 23 : Summit of Mount Arısama and Arısama Kalesi. 


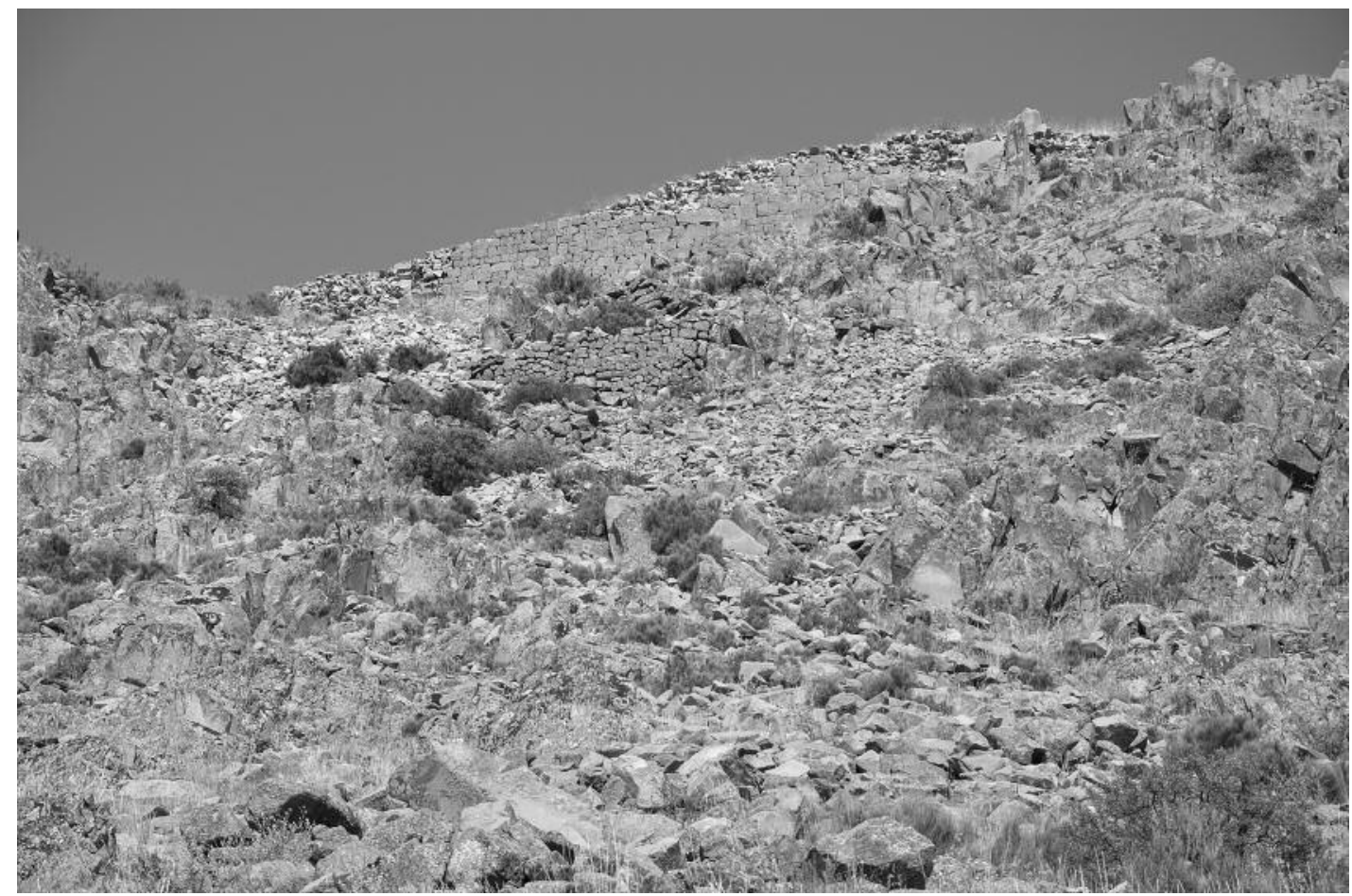

Fig. 24 : Eastern fortification wall of Arısama Kalesi.

date to the Byzantine period, however closer examination specifically of the fortification walls shows that there were several building phases. The foundations are cyclopean whereas in the upper part mortar was used. The Arisama castle is described by Belke, who mentions also Christian crosses carved on building blocks ${ }^{15}$.

During the survey only five sherds were found, among them one dating to the Middle Iron Age (the others were undiagnostic). In 2016 the castle will be visited again with the hope of finding more diagnsotic pottery. Belke underlines the strategic importance of this castle during the Byzantine period, to protect the hinterland against attacks from the southeast and the south after an enemy had approached through the Taurus Mouintans.

Mount Arisama is very likely to be equated with Hittite Mount Šarpa, mentioned on the Emirgazi altars. It is very likely that beneath the Byzantine castle a Hittite castle and temple is hidden, as the mountain was sacred to the Hittites. The one and only sherd indicates that this peak was also used during the Middle Iron Age, which underlines the strategic importance of this peak and mountain over a long time period.

\section{Acıdere Höyük (Fig. 25-26)}

Acıdere Höyük (Fig. 25) was shown to us by a villager. The settlement mound is $13.6 \mathrm{~km}$ east of Ereğli and $5.5 \mathrm{~km}$ north of Gökçeyazı village. The höyük is very low and large areas are damaged because of agricultural usage of the land. The real size is not possible to determine as it was difficult to find pottery because of dense vegetation on the surface. The owner had collected fifteen sherds, which date to the Chalcolithic, Early Bronze and Roman period (Fig. 26). No architectural remains were discovered.

\section{Survey in İvriz and Ambarderesi (Fig. 27-35)}

The investigation and survey in İvriz was conducted around the water cave, the hilltop above the cave, the space of the second relief ${ }^{16}$ of İvriz, the small building covered with a vault below the second relief, and the whole area around the main İvriz relief. In none of these mentioned locations was ancient pottery found. As mentioned before, there were many erosions and floods, so the ancient 


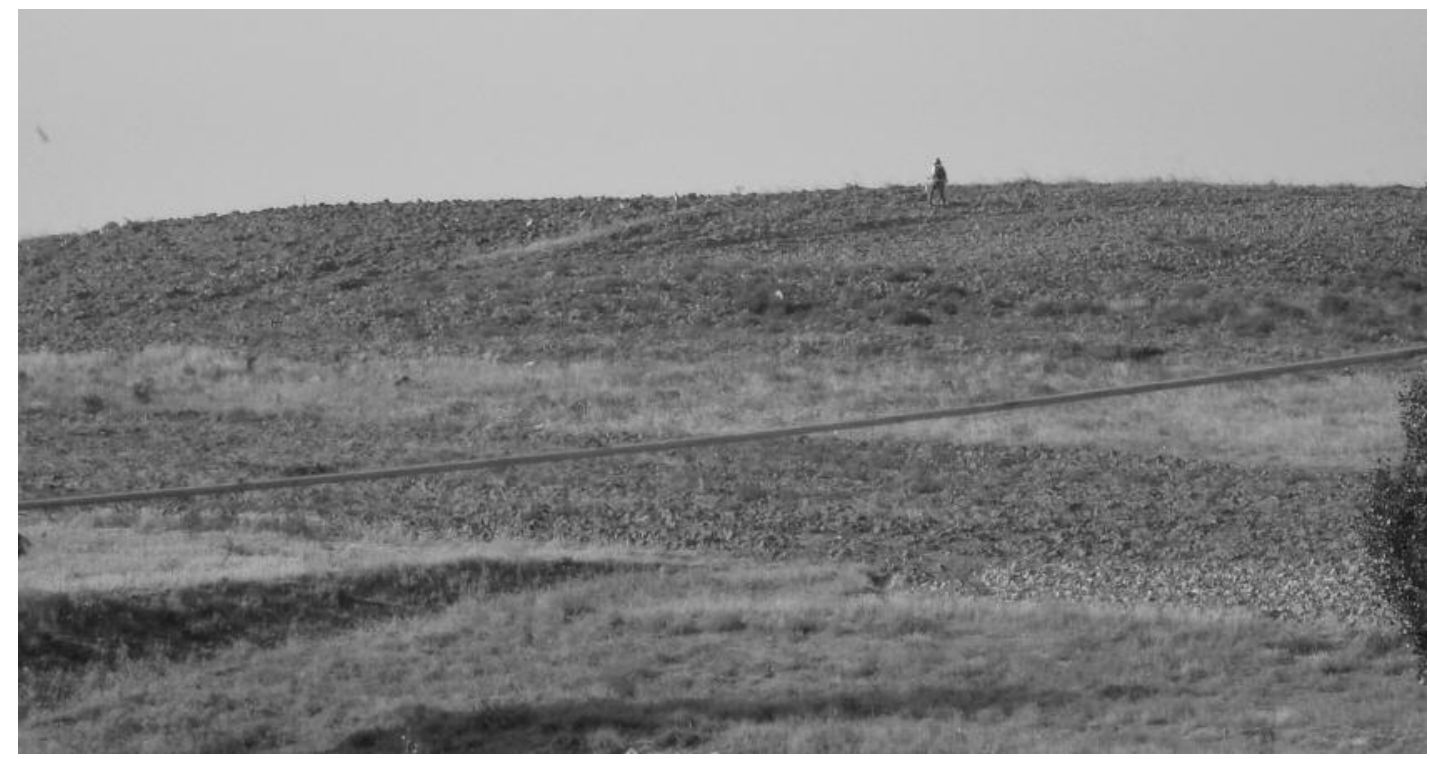

Fig. 25 : Acıdere Höyük.
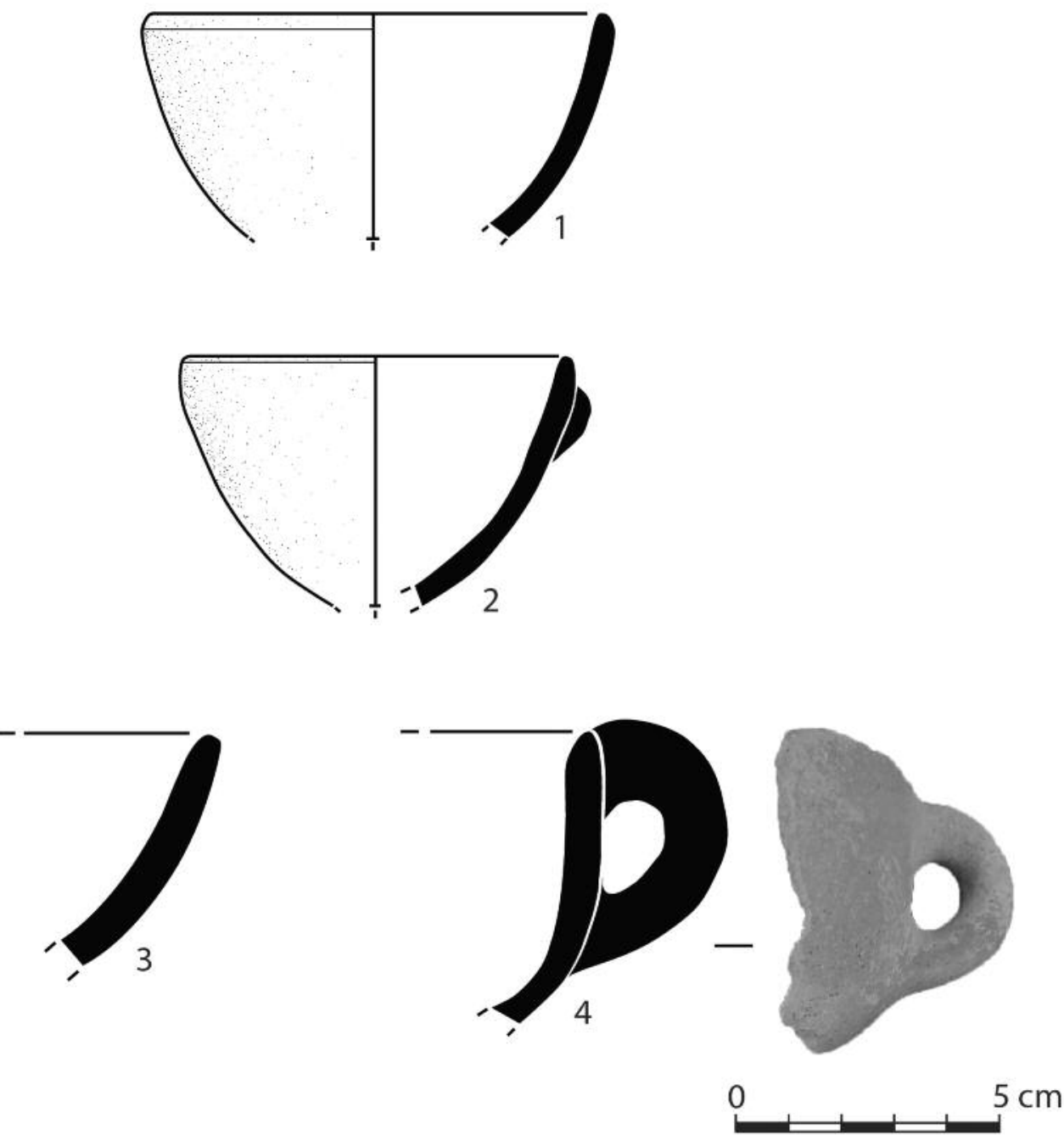

Fig. 26 : Pottery samples from Acıdere Höyük. 

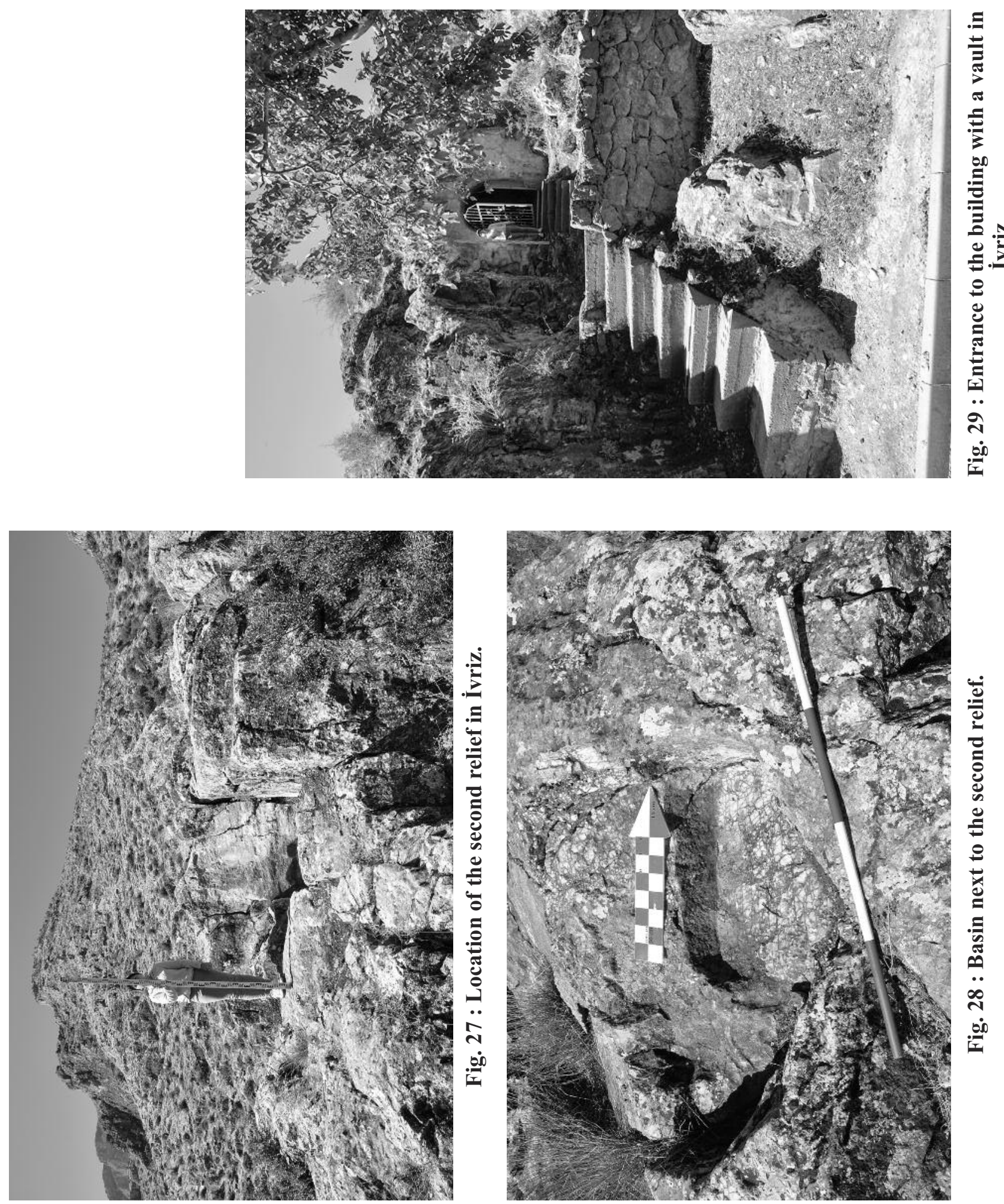


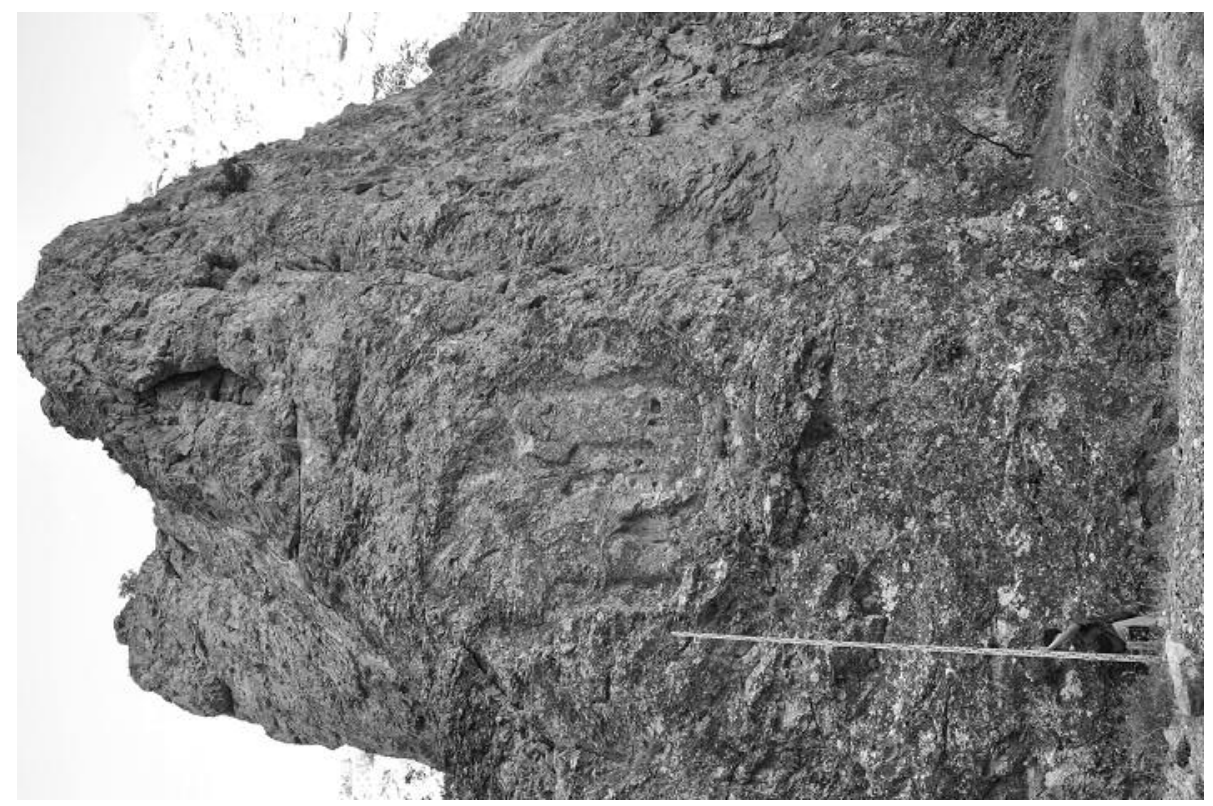

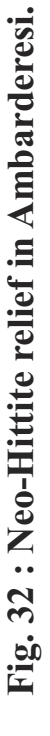
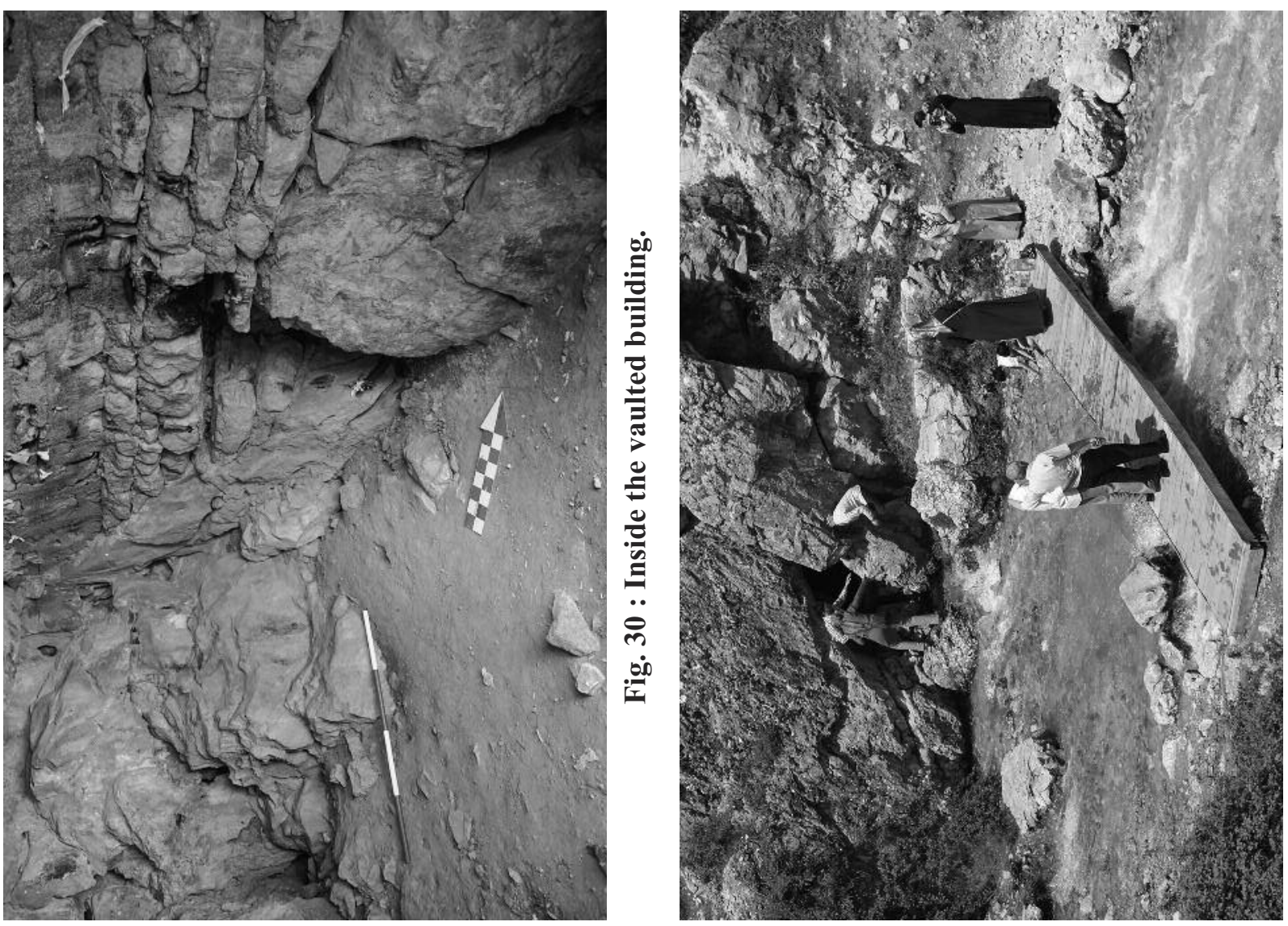

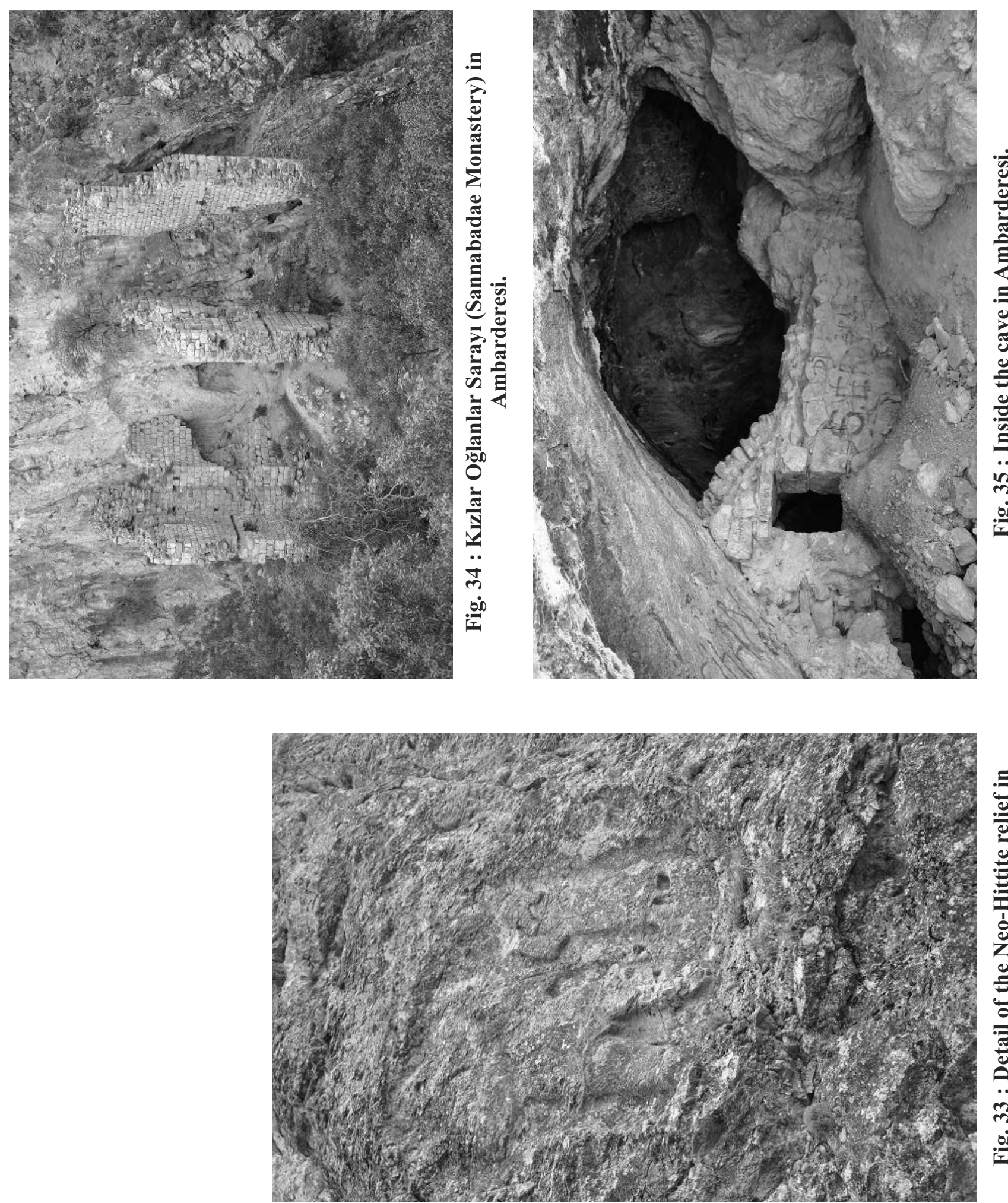

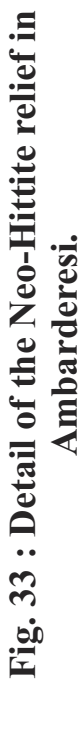


material is probably under a thick rubble layer ${ }^{17}$. The rock face that was once the second relief of İvriz $^{18}$ (Fig. 27) is disturbed by illicit excavations. The relief was facing north looking towards Tont Kalesi, probably the Hittite town of Hupišna, which is visible from this site ${ }^{19}$. Immediately to the west of the relief two steps are carved into the rock, which lead to a rectangular basin or indentation with rounded corners measuring $c a .65 \mathrm{~cm}$ x $55 \mathrm{~cm}$ (Fig. 28). This basin could be interpreted as an altar, sacrifice pit or a setting for a stele.

Just below the rock with the second relief is a small vaulted building (Fig. 29-30). Seven modern concrete steps lead to it and the entrance is closed with an iron door where visitors attach cloth pieces to mark their wishes. Locals call this building 'the Hittite Altar.' The building is $c a .2 .7 \mathrm{~m}$ wide and $6 \mathrm{~m}$ long. It is built adjacent to the rock face where the eastern and southern side of the cliff form natural walls. The lowest visible course of the eastern wall is built of very large boulders ( $c a .80-90 \mathrm{~cm})$, while the upper courses are made of medium sized stones fixed with mud. The vault is reminiscent of vaults of Late Antiquity, though the original structure is not very clear as it has been repaired with concrete. The small building resembles a chapel, which was perhaps built during Late Antiquty and was somehow connected with the Sannabadae monastery up in Ambarderesi. However, the large boulders and the fact that it is just below the small Hittite relief might indicate that this was originally built during the Hittite or NeoHittite period and was reused during Late Antiquty. Pottery has not been found here.

Around the water cave (Fig. 31), where water bubbles up from the ground during May-August, no ancient structure or pottery could be found.

The survey included also the area of Ambarderesi. The location known as Ambarderesi is around $7 \mathrm{~km}$ to the southwest of İvriz. A dry river bed leads up to the Taurus Mountains and to a Neo-Hittite relief ${ }^{20}$ (Fig. 32-33) that bears the same iconography as the main İvriz relief. However, this one does not have an inscription. The relief is carved on the western side of the hillside adjacent to the remains of a monastery which is known as Kılar Oğlanlar Saray1 by locals (Fig. 34). This was the Sannabadae

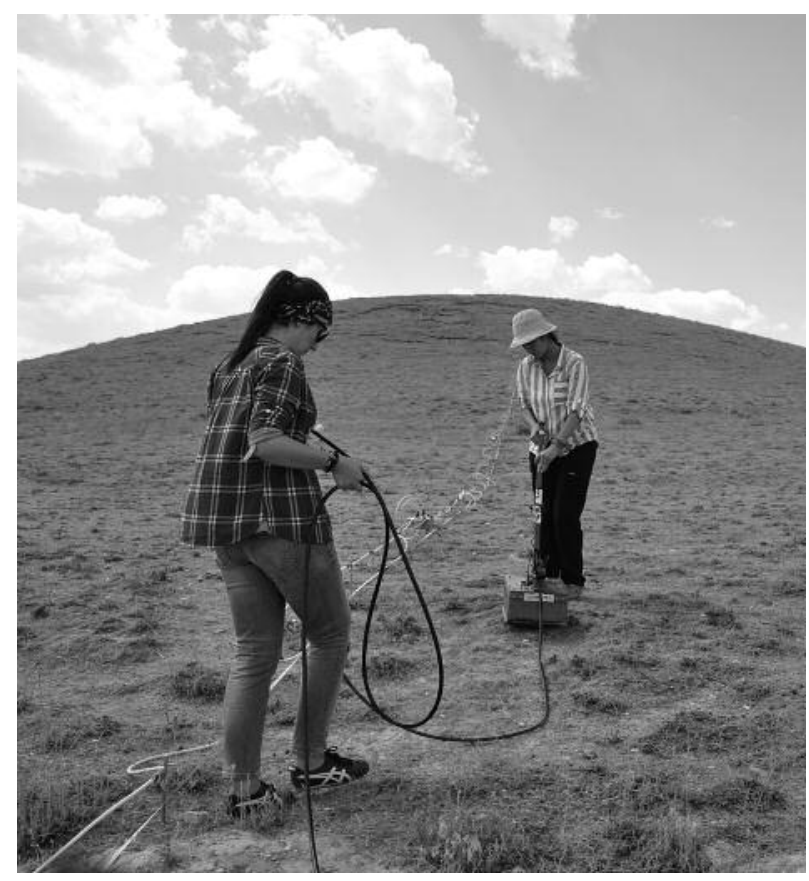

Fig. 36 : Remote sensing in Zencirli Höyük.

monastery where ascetic monks and nuns resided ${ }^{21}$. Due to lack of time the survey of this area was postoned to the forth season, when the cave next to the apsis will also be investigated.

\section{GEOPHYSICAL SURVEY (Fig. 36-38)}

A geophysical survey was conducted in Ereğli Karahöyük and Zencirli Höyük. These two höyüks belong to the group of large settlement mounds in this region. They had been surveyed in 2013 and 2014. Both sites are located close to the Cilician Gates and are sited on important road networks and close to mines in the Taurus Moutains. Both settlements show a continuity from the Early Bronze until the Middle Iron Age. The geophysical survey was conducted by Dr. Ercan Erkul from the University of Kiel in Germany and Mr. İsmail Kaplanvural and his students from Kocaeli University ${ }^{22}$. Three methods were applied on both settlements: resistivity (Fig. 36), magnotometry (Fig. 37) and geoelectric (Fig. 38). The publication of the results is forthcoming ${ }^{23}$.

17) This also explains why the stele and the head of a colossal Neo-Hittite sculpture were found under $7 \mathrm{~m}$ of rubble. They were published by Dinçol 1994.

18) Published extensively by Bier 1976.

19) Maner forthcoming.

20) Karauğuz and Kunt 2006.

21) Elm 1994: 184-205.

22) Publication forthcoming.

23) In preparation by E. Erkul and Ç. Maner. 


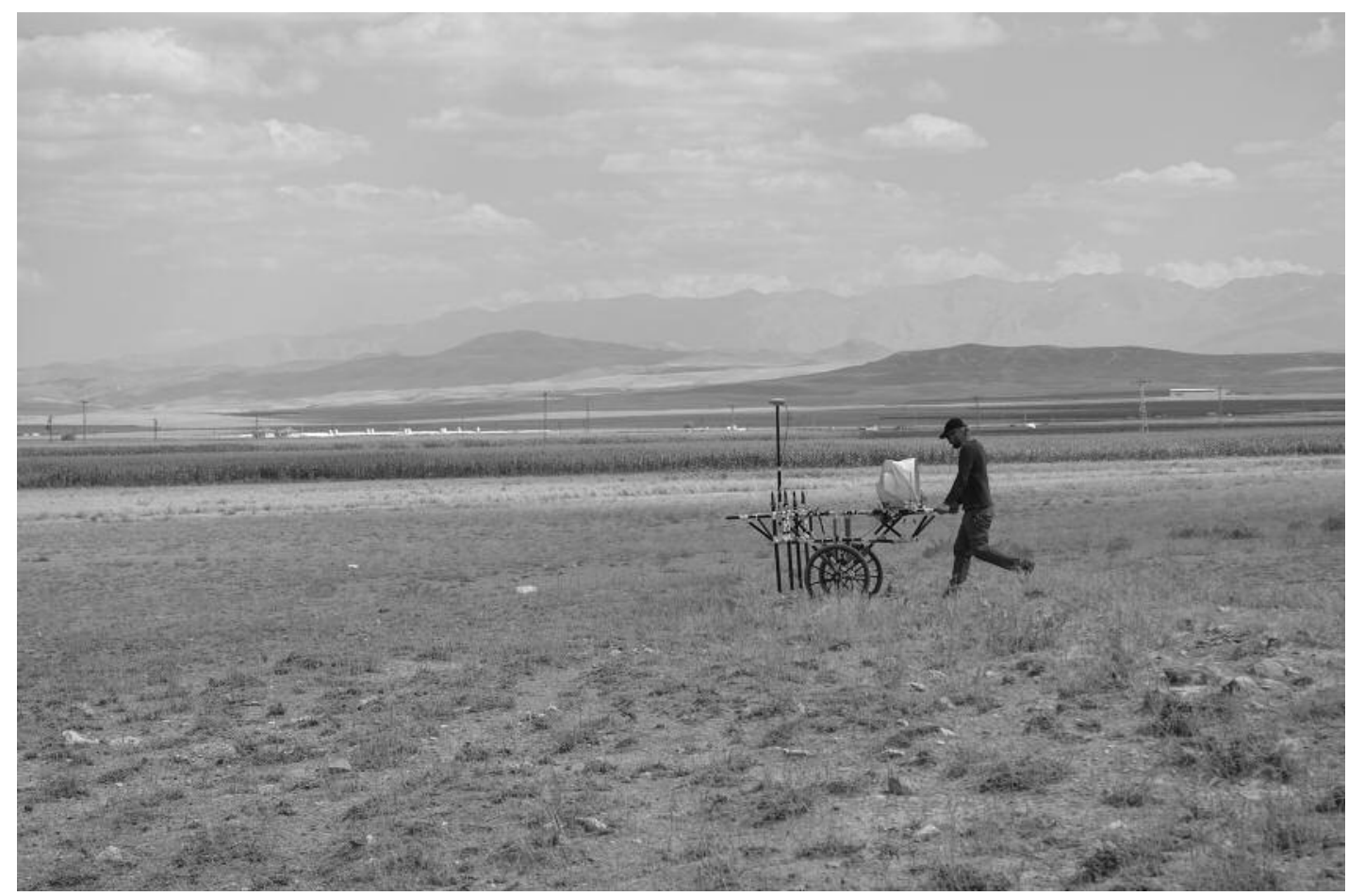

Fig. 37 : Geomagnetic survey in Zencirli Höyük.

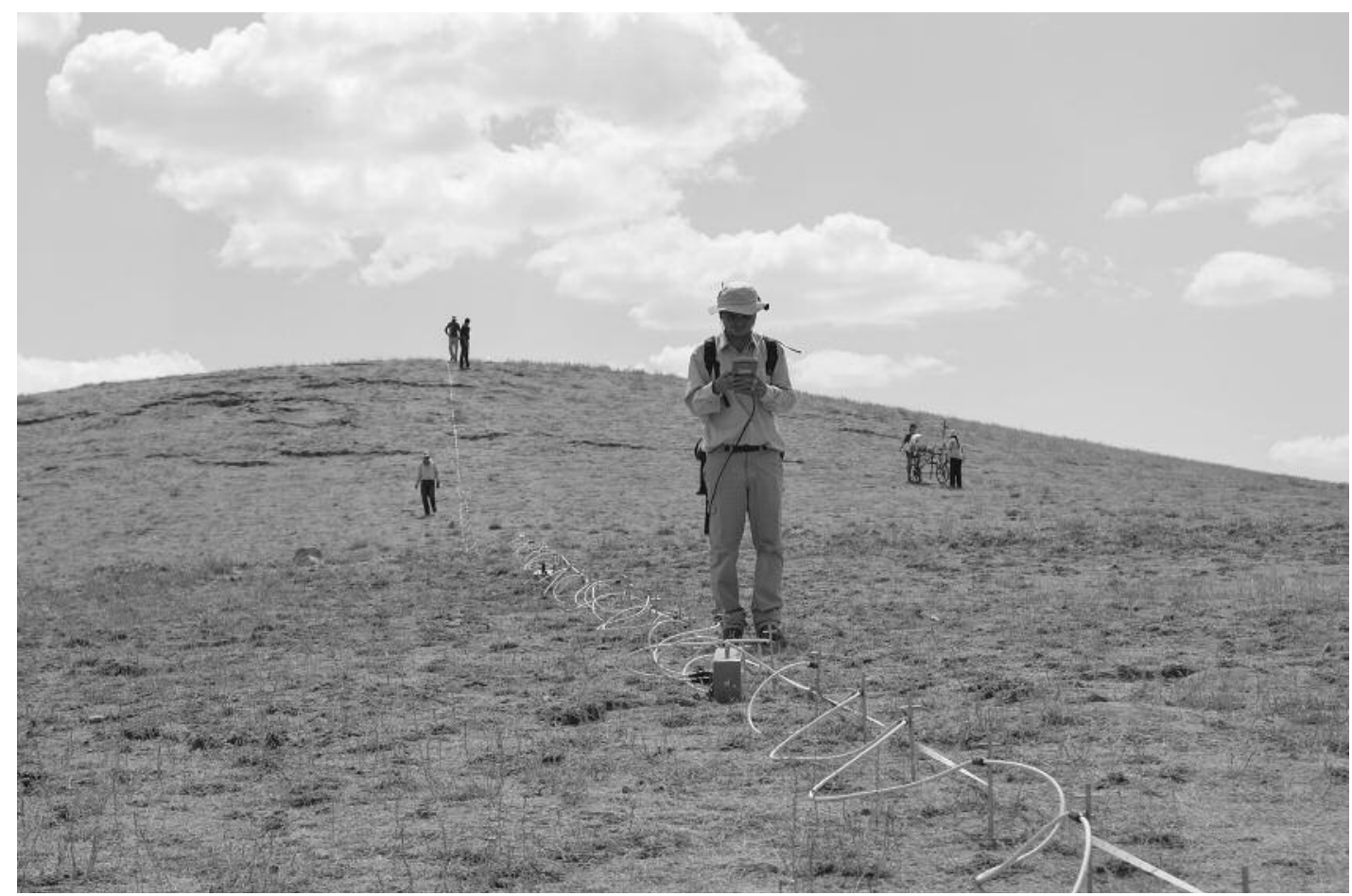

Fig. 38 : Geoelectric survey in Zencirli Höyük. 


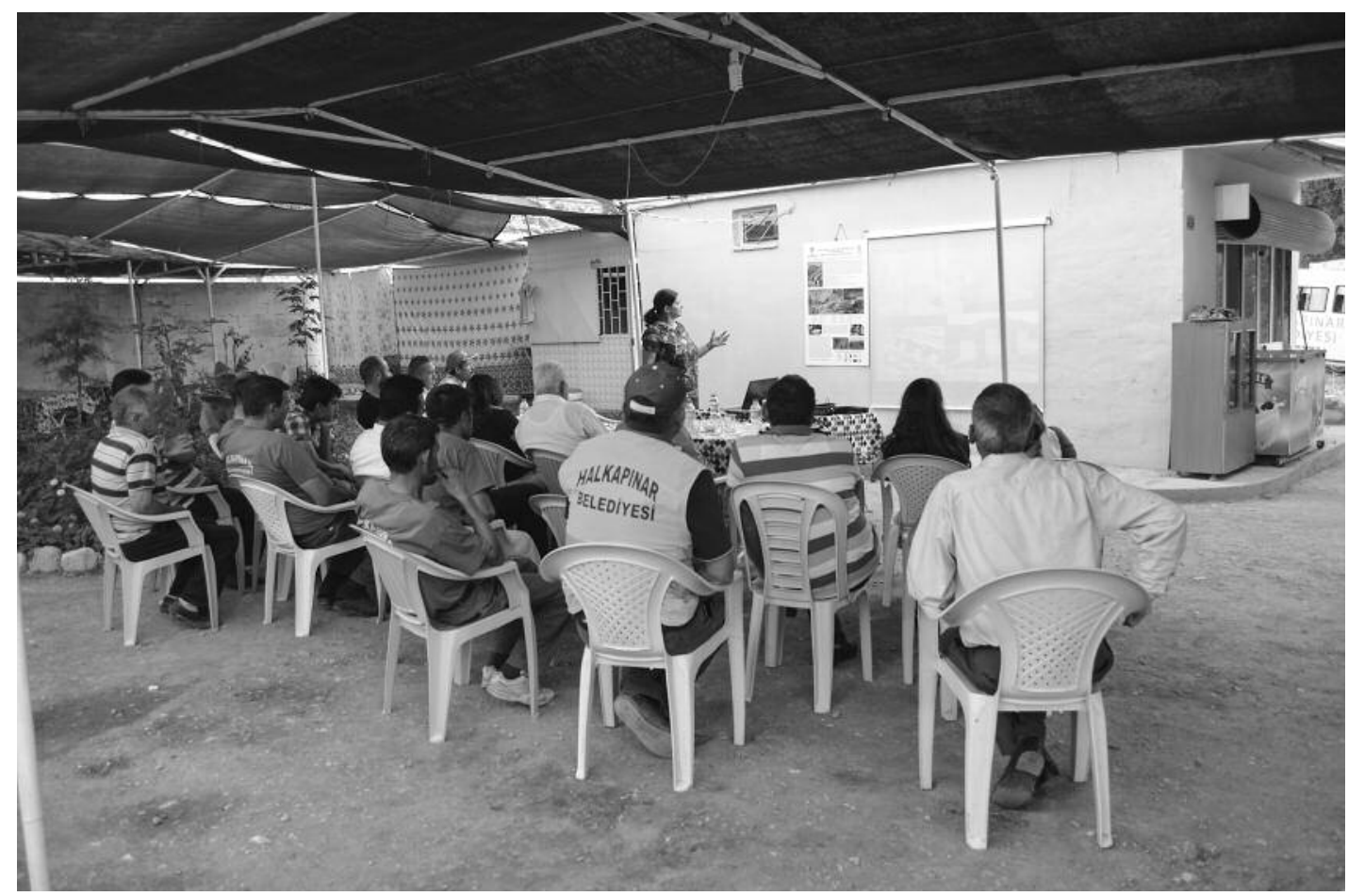

Fig. 39 : Seminar in İvriz for the staff of the municipality.

\section{COMMUNAL WORK (Fig. 39-42)}

İvriz receives from mid April until October minimum one thousand visitors on every weekend. The natural sweet water, which bubbles out of the ground from mid-April onwards is one of the reasons why people come here. Local people get their drinking water from these springs. During hot summer days locals and also visitors from Karaman, Niğde, Konya and Adana visit İvriz because it is cooler than the surrounding landscape and also it has picnic facilities. However, all of the natural resources are more abused rather than used. This includes also the archaeological remains. Since 2014 the municipality of Halkapınar asks for entrance fees to İvriz, mainly for the parking facilities. A problem which was recognized already in 2014 is that locals of İvriz take tourists around and communicate innacurate historical and archaeological information to visitors. For example, a common local myth told to visitors is that the Roman Empire was founded here in İvriz. The small Neo-Hittite relief (now in the Ereğli Museum), which orginally was located not far away from the water cave ${ }^{24}$, which bears two Hittite officials leading a ram or sheep to probably an altar, is interpreted by locals as Remus and Romulus, which they have

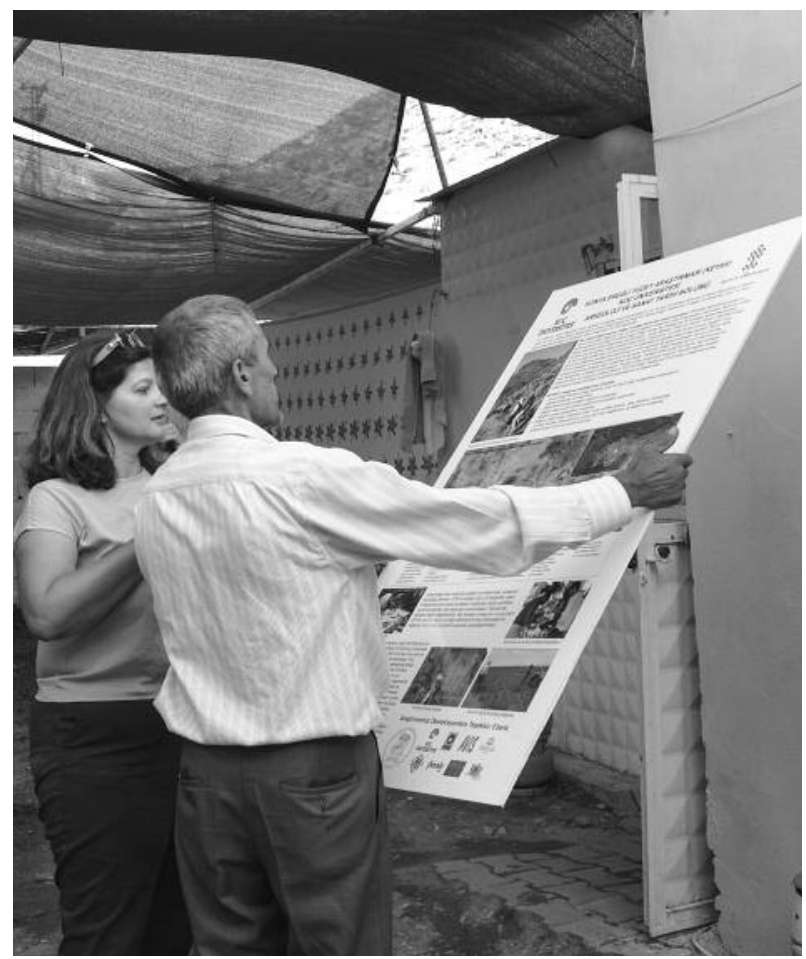

Fig. 40 : Distribution of information panels about the survey project. 


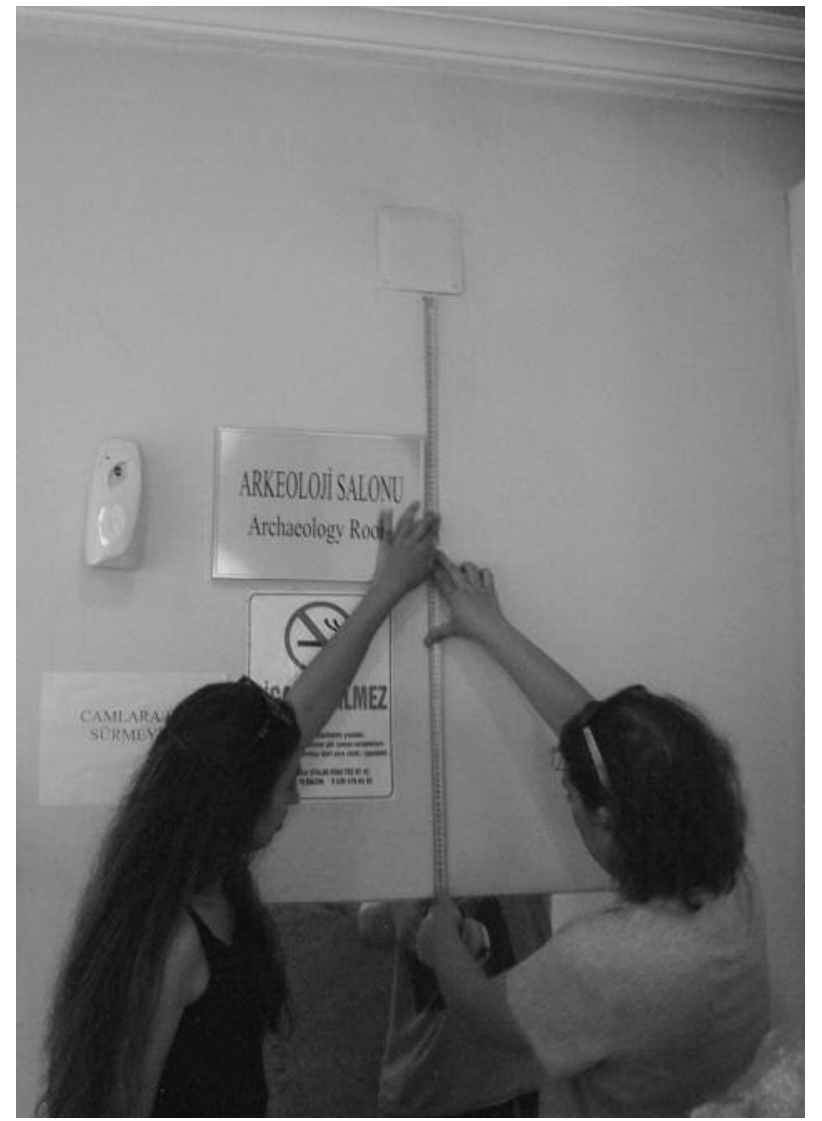

Fig. 41 : Preparation of the space for the information panel in the Ereğli Museum.

related to the foundation of the Roman Empire in İvriz!

In order to prevent this, a one day seminar about the history and archaeology of the region was conducted by the KEYAR-team for locals and workers of the municipality and prefecture of Halkapınar (Fig. 39). This will be continued also in the following years. Information panels on the KEYAR survey were gifted to every local stakeholder in Ereğli, Emirgazi and Halkapinar who had supported the survey project (Fig. 40) during the field season of 2015. These panels were also hung up in the Ereğli Museum, municipalities, and prefectures.

The Ereğli Museum exhibits important finds from İvriz. Among them are a bilingual stele, of which the lower part is preserved, and half of the head of a Neo-Hittite colossal sculpture which probably depicts King Warpalawas of Tuwanuwa. Both were discovered in İvriz in 1986 during construction

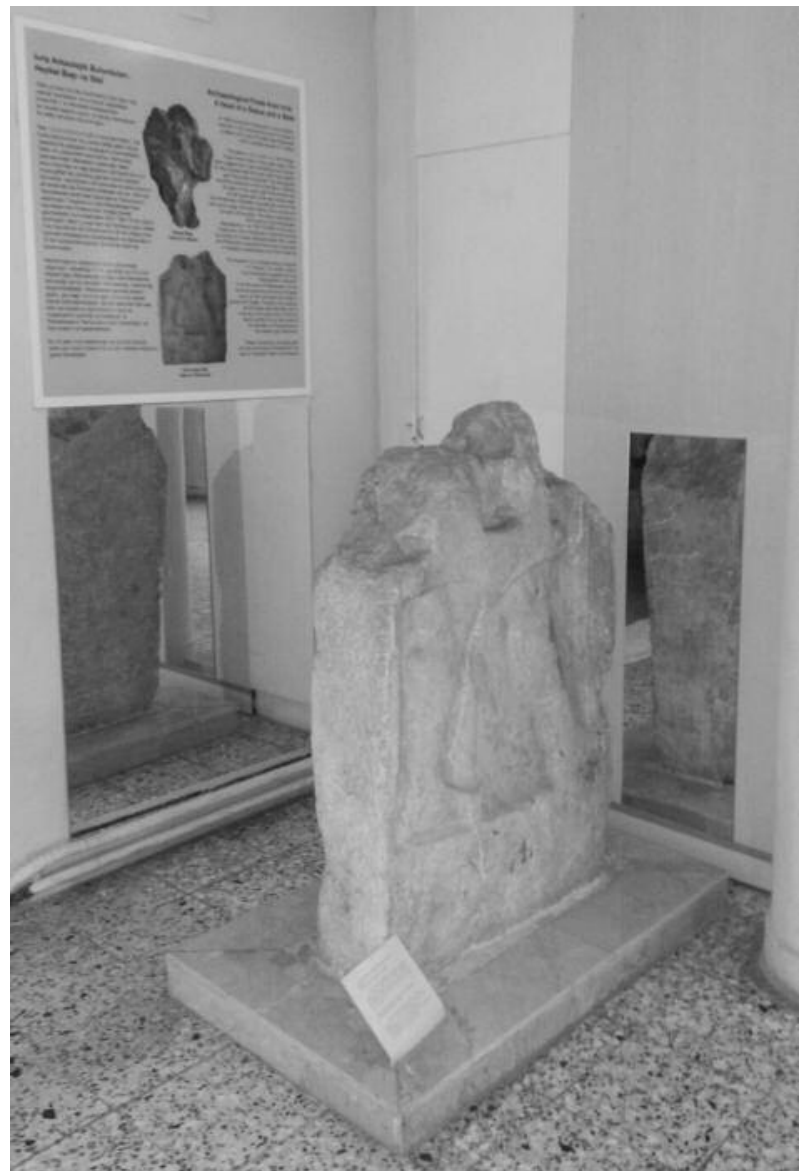

Fig. 42 : Bilingual stele from İvriz with mirrors and information panel.

work for canal pipes $c a .100 \mathrm{~m}$ east of the main relief ${ }^{25}$. An information panel about the stele and the head was prepared by the KEYAR-team and hung over the stele (Fig. 41). Mirrors were placed behind the fragment of the bilingual stele (Fig. 42), because the narrow space obstructed the view of the inscriptions on the back and left side.

\section{CONCLUSION (Fig. 43)}

The 2015 field season investigated the Halkapınar province, the regions west and south of Emirgazi, and the southern area around the dry Lake Akgöl. Specifically the survey in Halkapınar presents interesting results. As it is indicated in the article, a series of castles on the Taurus Mountains were located and surveyed (Map 2). Their function was to control the road networks from the Konya Plain down to the Mediterranean. Interviews with locals 


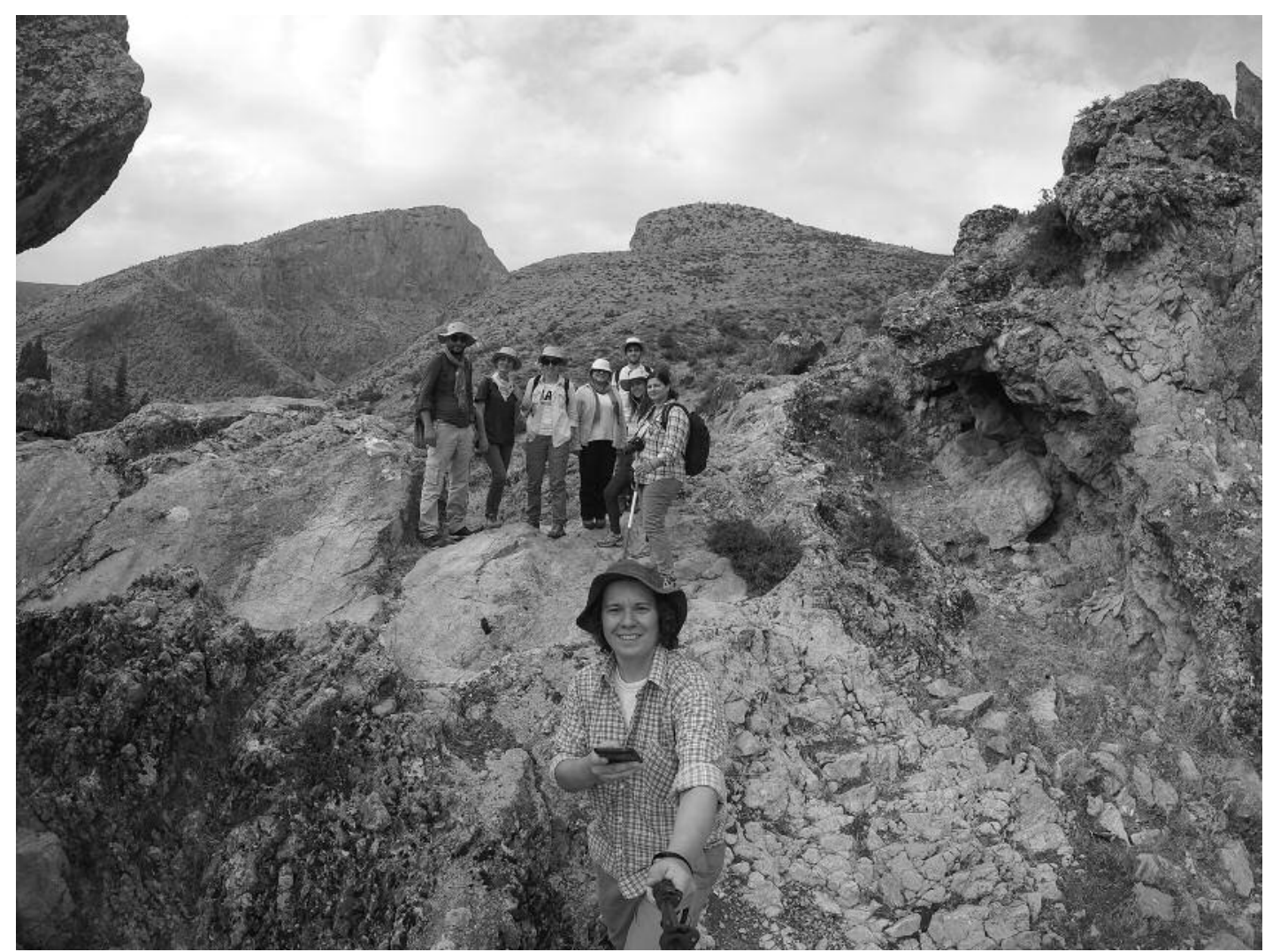

Fig. 43 : KEYAR 2015 team.

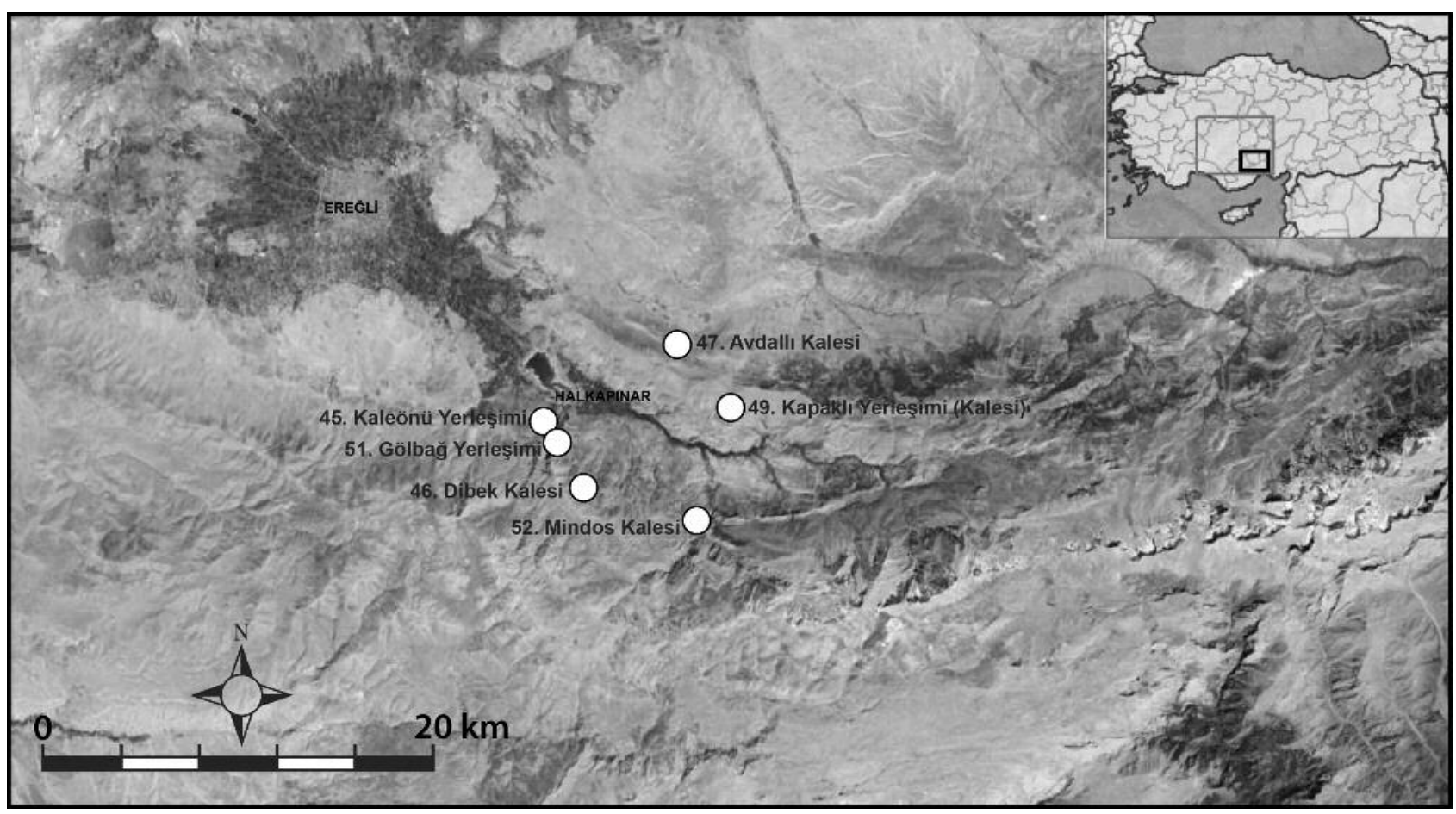

Map 2 : Network of castles/forts in the Taurus Mountains. 
point out that these roads are still used today by locals. Until now the Cilician Gate was considered the most important gateway from Central Anatolia to the Mediterranean. However, the castles and the roads connected to them show very clearly that there were also other roads which led down to the different regions of the Mediterranean. One of them was the road from the castles of Halkapinar via
Çamliyayla and from there down to the region of Mersin. A second interesting result is that the location where some of the Emirgazi altars were discovered revealed a large settlement with Second Millenium and Iron Age pottery. This would support the idea that a Hittite settlement was located here where Mount Šarpa was worshipped.

\section{BIBLIOGRAPHY} Wien.

Belke, K., 1984: Galatien und Lykaonien, TIB 4.

Bier, L., 1976: "A Second Hittite Relief at Ivriz", JNES 35/2: 115-126.

Börker-Klähn, J., 2007: "Die Schlacht um Tuanuua als 'Atlanta Storico' ", in Groddek, D. and Zorman, M. (eds.), Tabularia Hethaeorum: hethitologische Beiträge; Silvin Kosak zum 65. Geburtstag: 91-118, Wiesbaden.

Dinçol , B.,1994: "New Archaeological and Epigraphical Finds from Ivriz", Tel Aviv 21: 117 - 128.

Elm, S., 1994: 'Virgins of the God' The Making of Ascetism in Late Antiquity, Oxford.

Karauğuz, G. and Kunt, H.I., 2006: "İvriz kaya anıtları ve çevresi üzerine bir araştırma", Arkeoloji ve Sanat 122: 23 - 50 .
Hawkins, J.D., 1995: “Appendix 2. EMIRGAZI altars", The Hieroglyphic Inscription of the Sacred Pool Complex at Hattusa (Südburg), StBoT Beiheft 3: 86-102.

Maner, C.., 2014: "Preliminary Report on the First Season of the Konya-Ereğli (KEYAR) Survey 2013", Anatolia Antiqua XXII: 343-360.

- 2015a: "Preliminary Report on the Second Season of the Konya-Ereğli (KEYAR) Survey 2014", Anatolia Antiqua XXIII: 249-273

- 2015b: "Konya ili Ereğli, Halkapınar, Karapınar ve Emirgazi 2013 Yıılı Yüzey Araştırmaları (KEYAR)", AST 32/1: 27-46.

Maner, Ç. forthcoming: "Konya ili Ereğli, Halkapınar, Karapınar ve Emirgazi 2014 Yılı Yüzey Araştırmaları (KEYAR)", AST 33. 


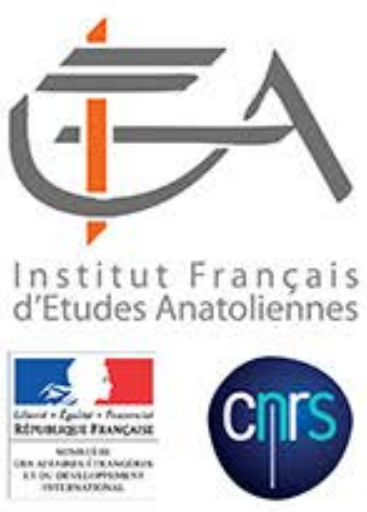

Eurômos : le temple de Zeus vu de l'Est (cliché Sönmez Alemdar).

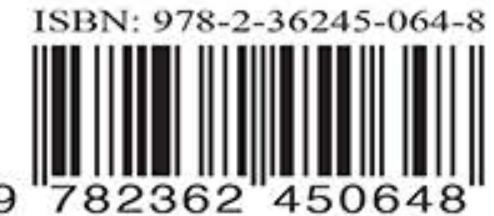

